\title{
Receptive Field Properties of Koniocellular On/Off Neurons in the Lateral Geniculate Nucleus of Marmoset Monkeys
}

\author{
(10) Calvin D. Eiber, ${ }^{1,2,3}$ Abrar S. Rahman, ${ }^{2}$ Alexander N.J. Pietersen, ${ }^{1,2,3}$ Natalie Zeater, ${ }^{1,2,3}$ Bogdan Dreher, ${ }^{2}$ \\ (D)Samuel G. Solomon, ${ }^{3,4}$ and $\odot$ Paul R. Martin ${ }^{1,2,3}$ \\ ${ }^{1}$ Save Sight Institute, ${ }^{2}$ School of Medical Sciences, ${ }^{3}$ Australian Research Council Centre of Excellence for Integrative Brain Function, University of Sydney, \\ Sydney, New South Wales 2000, Australia, and ${ }^{4}$ Department of Experimental Psychology, University College London, WC1P 0AH, London, England
}

The koniocellular $(\mathrm{K})$ layers of the primate dorsal lateral geniculate nucleus house a variety of visual receptive field types, not all of which have been fully characterized. Here we made single-cell recordings targeted to the K layers of diurnal New World monkeys (marmosets). A subset of recorded cells was excited by both increments and decrements of light intensity (on/off-cells). Histological reconstruction of the location of these cells confirmed that they are segregated to K layers; we therefore refer to these cells as K-on/off cells. The K-on/off cells show high contrast sensitivity, strong bandpass spatial frequency tuning, and their response magnitude is strongly reduced by stimuli larger than the excitatory receptive field (silent suppressive surrounds). Stationary counterphase gratings evoke unmodulated spike rate increases or frequency-doubled responses in K-on/off cells; such responses are largely independent of grating spatial phase. The K-on/off cells are not orientation or direction selective. Some (but not all) properties of K-on/off cells are consistent with those of local-edge-detector/impressed-by-contrast cells reported in studies of cat retina and geniculate, and broad-thorny ganglion cells recorded in macaque monkey retina. The receptive field properties of $\mathrm{K}$-on/off cells and their preferential location in the ventral $\mathrm{K}$ layers (K1 and K2) make them good candidates for the direct projection from geniculate to extrastriate cortical area MT/V5. If so, they could contribute to visual information processing in the dorsal ("where" or "action") visual stream.

Key words: lateral geniculate nucleus; primate; vision

Significance Statement

We characterize cells in an evolutionary ancient part of the visual pathway in primates. The cells are located in the lateral geniculate nucleus (the main visual afferent relay nucleus), in regions called koniocellular layers that are known to project to extrastriate visual areas as well as primary visual cortex. The cells show high contrast sensitivity and rapid, transient responses to light onset and offset. Their properties suggest they could contribute to visual processing in the dorsal ("where" or "action") visual stream.

\section{Introduction}

The two main divisions of the primate afferent visual system are named the parvocellular (P) and magnocellular (M) pathways, for the layers of the dorsal lateral geniculate nucleus (LGN) through which they pass. The $\mathrm{P}$ pathway serves high-acuity central foveal vision and red-green color vision, whereas the $\mathrm{M}$ path-

Received June 29, 2018; revised Sept. 12, 2018; accepted 0ct. 4, 2018.

Author contributions: A.S.R. wrote the first draft of the paper; A.N.J.P., B.D., and S.G.S. edited the paper; B.D., S.G.S., and P.R.M. designed research; C.D.E., A.S.R., A.N.J.P., N.Z., and P.R.M. performed research; C.D.E., A.S.R., A.N.J.P., N.Z., B.D., S.G.S., and P.R.M. analyzed data; C.D.E. and P.R.M. wrote the paper.

This work was supported by a National Health and Medical Research Council Project Grant (1042609) and the Australian Research Council Centre of Excellence for Integrative Brain Function (ARC Centre Grant CE140100007). We thank K. Cheong and A. Camp for help with data acquisition, and A. Demir and R. Masri for technical assistance.

The authors declare no competing financial interests.

Correspondence should be addressed to Paul R. Martin, Save Sight Institute, 8 Macquarie Street, Sydney 2001, NSW, Australia. E-mail: prmartin@physiol.usyd.edu.au.

https://doi.org/10.1523/JNEUROSCl.1679-18.2018

Copyright $\odot 2018$ the authors $\quad 0270-6474 / 18 / 3810384-15 \$ 15.00 / 0$ way serves motion perception and form vision at low contrast (for review, see Lennie and Movshon, 2005; Lee et al., 2010). A third division comprises cells located in the koniocellular/intercalated division of the LGN, about which less is known (for review, see Casagrande, 1994; Hendry and Reid, 2000; Kremers et al., 2005). Studies of koniocellular/intercalated cells (K-cells) in nocturnal primates Otolemur crassicaudatus (Greater bushbaby: Norton and Casagrande, 1982; Irvin et al., 1986) and Aotus trivirgatus (Owl monkey: Xu et al., 2001) revealed heterogeneous receptive field properties including concentric and nonconcentric spatial organization. In the best-studied diurnal primates (macaques and marmosets), K-cells include color-coding blueon and blue-off cells (Szmajda et al., 2006; Roy et al., 2009), suppressed-by-contrast cells (Tailby et al., 2007; Solomon et al., 2010), and orientation selective cells (Cheong et al., 2013).

There are several reasons to pay attention to K-cells. First, unlike $\mathrm{P}$ and $\mathrm{M}$ layers the $\mathrm{K}$ layers receive substantial direct inputs from several other subcortical visual centers (Harting et al., 1978; 
Stepniewska et al., 2000), suggesting visual functions additional to simple geniculocortical relay (for review, see Casagrande, 1994). Second, their diverse properties suggest that cortical input streams include functionally diverse parallel pathways, rather than functionally undifferentiated inputs which are then elaborated by intracortical circuits. Third, cortical projections of K-cells are more widespread than those of $\mathrm{P}$ and $\mathrm{M}$ cells, and include extrastriate cortical areas (Yukie and Iwai, 1981; Dick et al., 1991; Sincich et al., 2004). For these reasons K cells are implicated in serving residual "blindsight" visual functions that survive damage to primary visual cortex (V1): blindsight was demonstrated to depend on the LGN by Schmid et al. (2010). Finally, cortical projections of K-cells include supragranular layers of V1 (Fitzpatrick et al., 1983; Diamond et al., 1985; Hendry and Yoshioka, 1994; Klein et al., 2016), where they appear structurally similar to feedback pathways within the cortex (Maunsell and van Essen, 1983; Casagrande, 1994) and are hypothesized to coordinate activity both within and between different cortical areas (Jones, 2001).

In recordings from retina and LGN of rabbits (Levick et al., 1969; Vaney et al., 1981), rodents (Fukuda et al., 1979; Hale et al., 1979; Lennie and Perry, 1981; Heine and Passaglia, 2011), and guinea pigs (Demb et al., 2001a), on/off receptive fields are among the more common receptive field types. In contrast, most retinal ganglion cells and LGN cells in cats and primates are oncells or off-cells (Kuffler, 1953; Wiesel and Hubel, 1966; Cleland et al., 1976), with on/off cells less frequently encountered (Kozak et al., 1965; Stone and Fabian, 1966; Cleland and Levick, 1974; DeMonasterio, 1978; Troy et al., 1989; Solomon et al., 2010). In cats, on/off receptive fields are segregated to the ventral C laminae (Cleland et al., 1976; Wilson et al., 1976), and were assigned to the "W/sluggish" retinogeniculate visual pathway (Stone and Fukuda, 1974). One previous report detailed temporal response of four on/off cells in marmoset LGN (Solomon et al., 2010), and on/off cells with wide-field (broad-thorny) morphology in macaque retina were characterized by Puller et al. (2015). However, the detailed properties and LGN projection of on/off cells have not been reported.

Here we characterize an on/off class of $\mathrm{K}$ cell with properties resembling those of type $\mathrm{Vb}$ on/off ganglion cells recorded in macaque retina by de Monasterio (1978), broad-thorny cells recorded recently in macaque retina by Puller et al. (2015), and local-edge-detector/impressed-by-contrast receptive fields reported in studies of nonprimate retina and LGN. We show that on/off receptive fields form a functionally distinct part of the afferent visual pathway in marmosets.

\section{Materials and Methods}

Ethical approval. Procedures conformed to the Australian National Health and Medical Research Council (NHMRC) code of practice for the use and care of animals and were approved by the institutional animal care and ethics committee at the University of Sydney. Procedures also conform to the code of ethics of the World Medical Association (Declaration of Helsinki).

Animal preparation. Details of animal preparation, recording technique, and visual stimulation environment have been published previously (Tailby et al., 2008; Pietersen et al., 2014). To summarize, extracellular recordings of single units were performed in the LGN of common marmosets Callithrix jacchus. Animals were sedated with an intramuscular injection of Alfaxan $\left(12 \mathrm{mg} \cdot \mathrm{kg}^{-1}\right.$; Jurox $)$ and Diazepam ( $3 \mathrm{mg} \mathrm{kg}^{-1}$; Roche). Anesthesia and analgesia were maintained by continuous intravenous delivery of Sufentanil citrate $\left(6-30 \mu \mathrm{g} \cdot \mathrm{kg}^{-1} \mathrm{~h}^{-1}\right.$; Sufenta Forte, Janssen). Depth of anesthesia was monitored by continuous electroencephalography and pulse oximetry (SurgiVet). The animal was artificially respired with a $60 / 40 \%$ mixture of $\mathrm{NO}_{2}$-Carbogen $(5 \%$ $\mathrm{CO}_{2}$ in $\mathrm{O}_{2}$ ) and head-fixed in a stereotaxic frame. A durotomy was made above the LGN and a guide tube containing the recording electrode was inserted into the brain. Recording electrodes were routinely coated in DiI (Invitrogen) to assist in electrode track reconstruction. Action potential waveforms of single cells were discriminated by principal component analysis of amplified voltage signals from single microelectrodes (5-11 $\mathrm{M} \Omega, \mathrm{FHC}$ ). The position of each cell relative to the brain surface was recorded from a hydraulic microdrive (David Kopf, Model 640). Electrolytic lesions (3-6 $\mu \mathrm{A} \times 3-6 \mathrm{~s}$, electrode positive) were made to assist in track reconstruction. At the conclusion of recordings the animal was killed with an overdose of pentobarbitone sodium $\left(80-150 \mathrm{mg} \cdot \mathrm{kg}^{-1}\right.$, i.v.).

The position of recorded cells was reconstructed histologically as described in detail previously (White et al., 2001; Cheong et al., 2013). To summarize, post-euthanasia the animal was perfused with physiological saline $(0.9 \% \mathrm{NaCl})$ followed by $4 \%$ paraformaldehyde in $0.1 \mathrm{M}$ phosphate buffer ( $\mathrm{PB}), \mathrm{pH}$ 7.4. The skull was removed and the brain stored in a solution of glycerol ( $20 \%$ in $0.1 \mathrm{M} \mathrm{PB})$ for $3-5 \mathrm{~d}$ before sectioning. The brain was frozen-sectioned in coronal plane at $50 \mu \mathrm{m}$ thickness and stained for Nissl substance or with NeuroTrace (Life Technologies), for fluorescence. The brain and electrode tracks were visualized using a universal microscope (Zeiss Axioplan-2). DiI-stained tracks, geniculate layers and the location of electrolytic lesions are clearly visible (see Fig. 2A), allowing reconstruction of the location of individual cells along the electrode track. Locations of 7 of our $17 \mathrm{~K}$-on/off cells were reconstructed in this manner, along with 2 cells which showed on/off response profiles but did not yield enough data to justify further analysis. In cases where cell location could not be reconstructed, the receptive field properties, eye dominance, encounter position, and response characteristics of nearby cells in the track (typically, presence of blue-on and blue-off cells) were used as criteria. Reference populations of P cells $(n=110)$, M cells $(n=100)$, and koniocellular blue-on (K-bon) cells $(n=56)$ was drawn from a larger database of recordings conducted under as close as possible identical recording conditions. Some properties of these cells were described previously (Pietersen et al., 2014; Eiber et al., 2018); all responses were reanalyzed for the present study. Responses of a small population of orientation-selective K cells (K-ori, $n=8$; Cheong et al., 2013) were also reanalyzed. A small number (5/17) of the K-on/off cells were included in previous descriptions of the K pathways by our laboratory (White et al., 2001; Solomon et al., 2010); all responses were reanalyzed for the present study. Overall, data are drawn from 26 animals.

Visual stimuli. Visual stimuli (drifting sine-wave modulated gratings, flashing dots, and stationary sine-wave modulated counterphase gratings) were displayed on a stimulus monitor (G520, Sony; refresh rate 100 $\mathrm{Hz}$, or VIEWPixx, Vpixx Technologies, refresh rate $120 \mathrm{~Hz}$ ) against a gray background (mean luminance $\sim 50 \mathrm{~cd} / \mathrm{m}^{2}$ ) and centered on each receptive field using a front-silvered gimbaled mirror. For data reported here the non-dominant eye was occluded with an opaque shutter. Most of the stimuli used were achromatic luminance stimuli which modulate the three cone classes equally. Cone-selective ("silent substitution") stimuli were also generated by adjusting the driving voltage of the red, green, and blue phosphors of the stimulus monitor, using the spectral radiance distribution of the monitor phosphors, the sensitivity distribution of the marmoset cone photoreceptors, and knowledge of the spectral absorbance of the optic media and macular pigment (Brainard, 1996; Tailby et al., 2008). Visual stimuli were generated using custom software which also collected and sorted recorded spike waveforms and times to within $0.1 \mathrm{~ms}$ (EXPO; P. Lennie, University of Rochester, Rochester, $\mathrm{NY}$ ). Recorded spike time-stamps were corrected post hoc for time delays (17-25 ms) because of the stimulus generation and presentation equipment. After correcting for differences across stimulus equipment, we found no systemic differences between response latencies recorded in different animals. No systematic differences in responses to short wave sensitive (S) cone stimulation were found between trichromatic female animals (identified by the presence of red-green opponent parvocellular cells), and the other dichromatic animals, all of which had a visual phenotype consistent with the presence of $S$ cones and one cone type with 

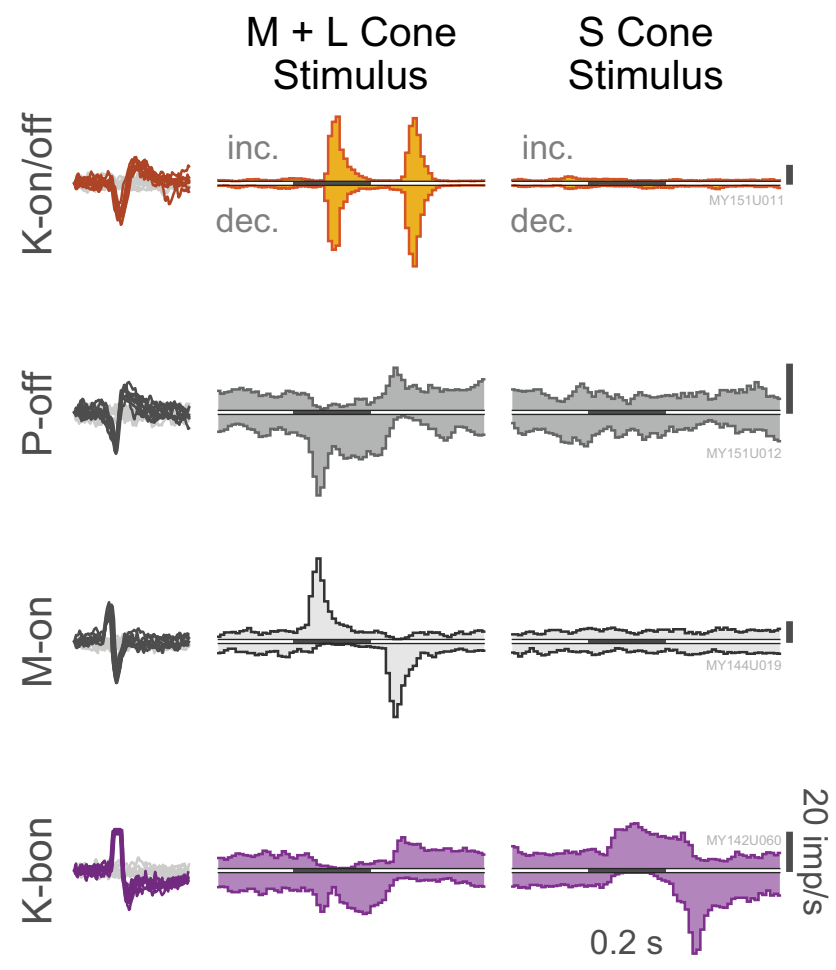

Figure 1. Response profiles of a typical K-on/off cell, P-off cell, M-on cell, and K-bon cell to small uniform increments (inc.) and decrements (dec.) of $\mathrm{M}+\mathrm{L}$ and S-cone contrast. Scale bars, $20 \mathrm{imp} / \mathrm{s}$. Isolated spike waveforms for these cells are also shown superimposed against noise threshold crossings. Cells were recorded at $3.1^{\circ}, 1.7^{\circ}, 1.6^{\circ}$, and $2.2^{\circ}$ eccentricity from the fovea, respectively. Histograms are binned at $10 \mathrm{~ms}$ resolution, and have been smoothed using a three-point moving average.

peak sensitivity close to 543,556 , or $563 \mathrm{~nm}$ (ML cones), so data from different phenotypes were pooled for analysis.

Response characterization. Spike trains were analyzed offline using MATLAB (R2015a, MathWorks). Analytic models, described in more detail below, were fit to drifting and counterphase grating responses. To characterize the temporal response properties of on/off cells, responses to small, brief $(200 \mathrm{~ms})$ increments and decrements in S-cone excitation, ML-cone excitation and achromatic luminance were averaged over 100 presentations and spike-times were binned using 2 ms bins. Response profiles were smoothed using local weighted regression (MATLAB function loess) across a span of $35 \mathrm{~ms}$, and the median maintained discharge rate was subtracted. Latencies were calculated for each cell from the earliest time bin post-preferred-stimulus in which the firing rate exceeded the $99 \%$ confidence interval of the smoothed, averaged response to blank screen stimuli, which were randomly interleaved with spot stimuli. The time to peak is the delay between the response onset and the first maximum (or minimum) poststimulus. The transience index is given by one minus the ratio of the mean response $100-200$ ms post-response onset to the maximum response. This technique produces estimates of response latency, time to peak, and transience which are in close agreement with our previously published results (Pietersen et al., 2014). This test was run on $11 \mathrm{on} / \mathrm{off}$ cells, $91 \mathrm{P}$ cells, and $81 \mathrm{M}$ cells.

Responses to both drifting sinusoidal gratings and stationary sinemodulated counterphase gratings were analyzed using Fourier analysis. The change in mean discharge rate ( $\mathrm{f} 0$ ) as well as the amplitude of the first (linear, f1) and second (frequency-doubled, f2) harmonics of the stimulus were extracted. As shown below (see Results), K-on/off cells responded nonlinearly to most stimuli; responses to drifting gratings were primarily characterized by elevations in $\mathrm{f} 0$, unlike the more linear $\mathrm{P}$ and $\mathrm{M}$ cells which had a phase-locked $\mathrm{f} 1$ response to stimulation.

Achromatic drifting gratings of varying contrast were presented to 17 on/off cells, $110 \mathrm{P}$ cells, $100 \mathrm{M}$ cells, $6 \mathrm{~K}$-ori cells, and $22 \mathrm{~K}$-bon cells. The $\mathrm{K}-\mathrm{bon}$ cells were characterized using responses to S-cone-isolating,
A

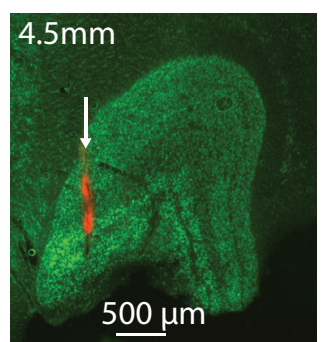

C

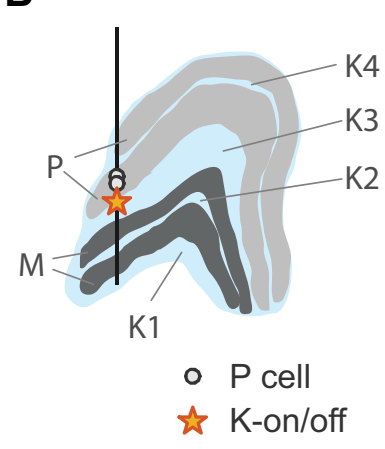

3.5

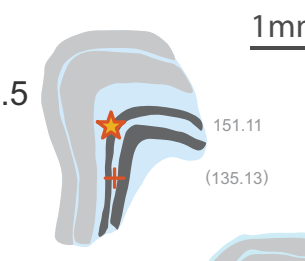

P Layer

M Layer

K Layer

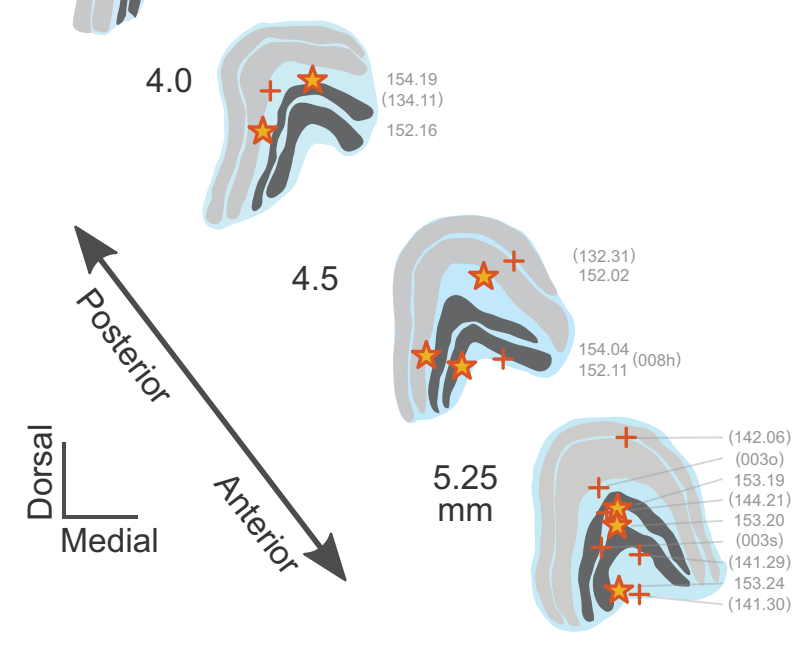

Figure 2. Anatomical reconstruction of K-on/off cell positions. A, coronal section through the LGN (4.5 mm anterior to intra-aural line) stained with NeuroTrace (green) and Dil (red), showing the layers of the LGN and electrode track (arrow). $\boldsymbol{B}$, Reconstructed positions of two $P$ cells and one K-on/off cell recorded in this track. C, Reconstructed positions of K-on/off cells (star symbols) shown relative to representative $L G N$ profiles. The positions of the other K-on/off cells were estimated from receptive field location and eye dominance relative to other cells recorded on the same track ( + symbols).

rather than achromatic, gratings. Responses were fit to saturating hyperbolic functions (Naka and Rushton, 1966; Sclar et al., 1990) of the following form:

$$
K=\frac{M c}{c+c_{50}}+b
$$

in which the spike rate $K$ is a function of stimulus contrast $c$, theoretical maximum spike rate $M$, semisaturation contrast $c_{50}$ (at which the response is at half of maximum), and maintained discharge $b$. The contrast gain is the derivative of Equation 1 at zero contrast, and is given by the ratio of the maximum spike rate to the $C_{50}$. Fits were performed in MATLAB using constrained nonlinear least-squares minimization in which the semisaturation contrasts $\mathrm{C}_{50}$ were constrained between 0 and $200 \%$ (as $C_{50}$ increases, Eq. 1 increasingly approximates a straight line; permitting the $\mathrm{C}_{50}$ to increase beyond $200 \%$ did not increase fit quality). For the purpose of model identification, the residual errors of this model were compared with a simple linear model (in which the response is proportional to contrast) as well as to an extended model with an exponent term $n$ permitting expansive contrast curves: 

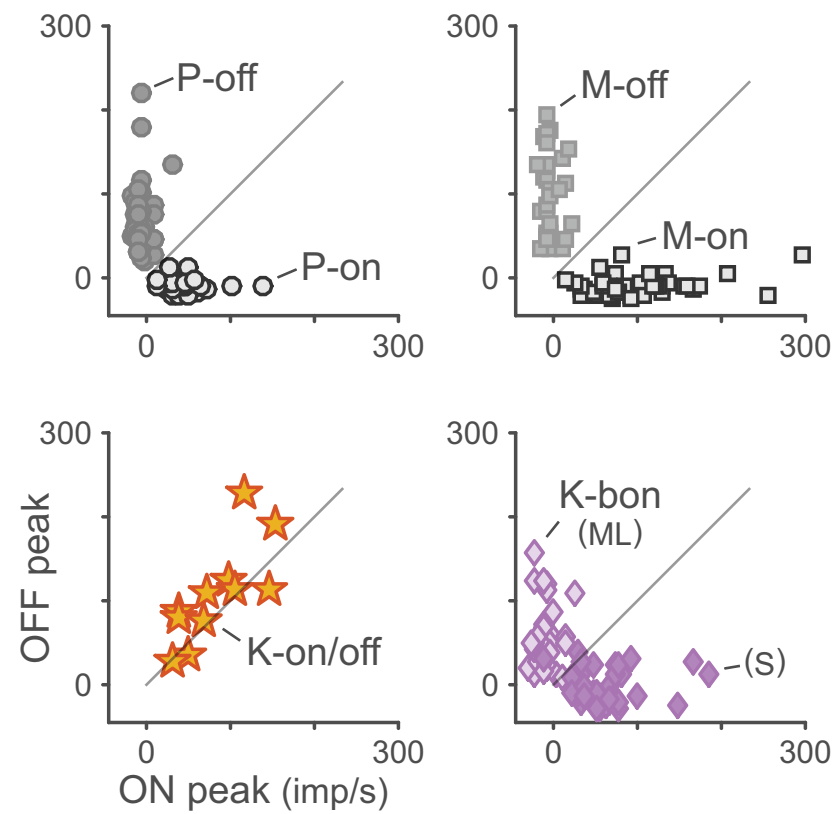

Figure 3. Scatterplots of responses to luminance increments ( $O N$ ) and decrements (OFF) for $\mathrm{K}$-on/off, $\mathrm{P}, \mathrm{M}$, and K-bon cells. P and $\mathrm{M}$ cells are suppressed by their anti-preferred stimulus. $\mathrm{K}$-on/off cells are excited by both stimuli approximately equally. K-bon cells are excited by S-cone increments and ML-cone decrements, and suppressed by S-cone decrements and MLcone increments.

Table 1. Location and eye dominance of koniocellular on/off cells

\begin{tabular}{lllll}
\hline & \multicolumn{2}{l}{ Layer } & & \\
\cline { 2 - 5 } Eye dominance & K1 & K2 & K3 & K4 \\
\hline Ipsilateral & 0 & 4 & 4 & 2 \\
Binocular & 0 & 0 & 1 & 0 \\
Contralateral & 5 & 1 & 0 & 0 \\
\hline
\end{tabular}

$$
K=\frac{M\left(c^{n}\right)}{c^{n}+c_{50}^{n}}+b,
$$

with other variables following Equation 1. Values of the expansive exponent term were constrained to be $>1$ and $<3$, so that gain of the cell could be estimated for low amplitude responses. The models were compared using a one-sided two-sample $F$ test for equal variances (Eiber et al., 2018).

Direction and orientation selectivity were systemically investigated in $9 \mathrm{~K}$-on/off cells, $8 \mathrm{~K}$-ori cells, $36 \mathrm{P}$ cells, and $30 \mathrm{M}$ cells using achromatic drifting gratings, as well as in $12 \mathrm{~K}$-bon cells using cone-isolating drifting gratings. The direction selectivity index (DSI) can be quantified by computing the vector sum of the responses at different orientations then divided by the scalar sum (Levick and Thibos, 1982; Cheong et al., 2013):

$$
D S I=\left|\frac{\sum r_{n} e^{i \theta_{n}}}{\sum r_{n}}\right| .
$$

In which $r_{n}$ is the response (in imp/s) to a stimulus moving in direction $\theta_{n}, e$ is the natural exponent, and $i$ is the imaginary unit $\sqrt{-1}$. The DSI varies from 0 (equal response to all directions) to 1 (response to only a single direction). Orientation selectivity is calculated in parallel fashion by doubling the angle:

$$
O S I=\left|\frac{\sum r_{n} e^{2 i \theta_{n}}}{\sum r_{n}}\right|,
$$

and quantifies the extent to which cell responses are modulated by orientation, independent of the direction of drift. Orientation selectivity
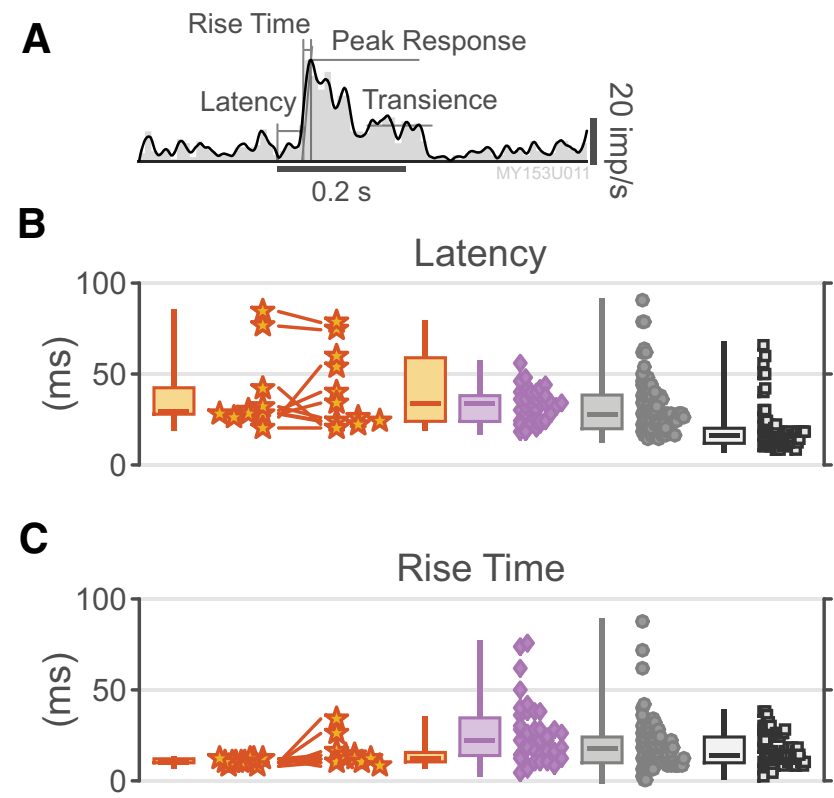

D

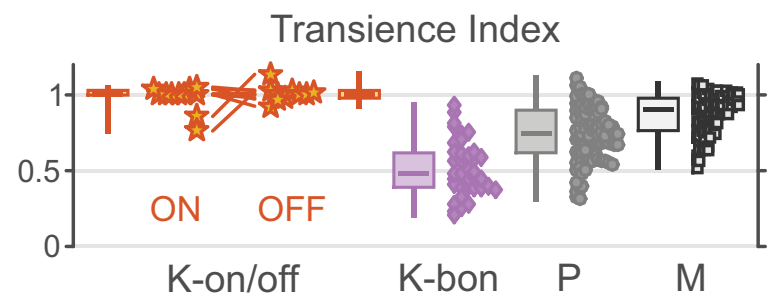

Figure 4. K-on/off cell temporal response properties. A, PSTH demonstrating LOESS regression line, onset latency, peak response, rise time, and sustained response for an example $P$ on cell. $\boldsymbol{B}-\boldsymbol{D}$, Distributions of onset latency, rise time, and transience index for K-on-off cells, K-bon cells, P cells, and M cells. Measurements for K-bon cells are derived from S-cone stimuli; metrics for other cells are derived from $\mathrm{M}+\mathrm{L}$-cone stimuli. Responses to both increments and decrements are shown for K-on/off cells.

arising from elliptical receptive fields is spatial-frequency-dependent (Levick and Thibos, 1982; Soodak et al., 1987; Cheong et al., 2013), and orientation tuning curves were often measured at multiple spatial frequencies. For each cell, orientation selectivity index (OSI) and DSI are calculated from gratings having the spatial frequency that maximized the orientation selectivity (within the set of spatial frequencies tested), subject to the constraint that the peak response be at least 10 spikes/s. The reader should note that these criteria differ from those used in our previous study of K-ori cells (Cheong et al., 2013), in which we measured orientation tuning at the optimal spatial frequency. The criteria we used here will yield slightly higher OSI and DSI values than in our previous study.

Achromatic drifting gratings of varying spatial frequency were presented to $15 \mathrm{on} / \mathrm{off}$ cells, $97 \mathrm{P}$ cells, and $92 \mathrm{M}$ cells. To characterize responses we used a standard difference-of-Gaussians model (Rodieck and Stone, 1965; Enroth-Cugell and Robson, 1966) of the following form:

$$
K=\pi k_{c} r_{c}^{2} e^{-\left(\pi r_{c} \omega\right)^{2}}-\pi k_{s} r_{s}^{2} e^{-\left(\pi r_{c} \omega\right)^{2}},
$$

where spike rate $K$ is a function of the strength of the center and surround (given by $k_{c}$ and $k_{s}$ ) and the radius of the center and surround (given by $r_{c}$ and $r_{s}$ ), for an input stimulus $\omega$ (in cycles/degree). From Equation 5 we computed the spatial frequency index (Cheong et al., 2013):

$$
S F I=1-\frac{K_{u}}{K_{p}},
$$




\begin{tabular}{|c|c|c|c|c|c|}
\hline & $\begin{array}{l}\text { Increment response } \\
\text { amplitude, imp/s }\end{array}$ & $\begin{array}{l}\text { Decrement Response } \\
\text { amplitude, imp/s }\end{array}$ & $\begin{array}{l}\text { Response onset } \\
\text { latency, ms }\end{array}$ & $\begin{array}{l}\text { Response rise } \\
\text { time, ms }\end{array}$ & Transience index \\
\hline K-on/off (on-response; $n=11$ ) & $83.6 \pm 43.5$ & & $29.42 \pm 6.22$ & $10.36 \pm 1.50$ & $0.98 \pm 0.09$ \\
\hline K-on/off (off-response; $n=11$ ) & & $106.7 \pm 60.0$ & $30.67 \pm 11.59$ & $15.27 \pm 7.81$ & $1.01 \pm 0.05$ \\
\hline K-bon S-cone $(n=39)$ & $64.4 \pm 39.9$ & $-2.7 \pm 19.9$ & $35.38 \pm 20.31$ & $25.90 \pm 17.19$ & $0.52 \pm 0.18$ \\
\hline K-bon ML-cone $(n=39)$ & $-10.0 \pm 12.7$ & $61.1 \pm 43.1$ & $55.89 \pm 29.74$ & $32.62 \pm 28.14$ & $0.43 \pm 0.32$ \\
\hline P-on $(n=37)$ & $44.6 \pm 24.4$ & $-8.6 \pm 7.5$ & & & \\
\hline P-off $(n=54)$ & $-5.7 \pm 8.5$ & $70.0 \pm 42.4$ & $32.81 \pm 19.58$ & $19.36 \pm 13.67$ & $0.74 \pm 0.18$ \\
\hline M-on $(n=47)$ & $98.2 \pm 58.3$ & $-9.8 \pm 11.8$ & & & \\
\hline M-off $(n=34)$ & $-3.0 \pm 10.2$ & $98.8 \pm 49.1$ & $18.98 \pm 11.61$ & $16.47 \pm 8.43$ & $0.87 \pm 0.13$ \\
\hline
\end{tabular}

Amplitude measures are given relative to maintained discharge rates.

where SFI is the spatial frequency index, $K_{u}$ is the response to a uniform field and $K_{p}$ is the peak response amplitude. The SFI measure is 1 when the response to a uniform stimulus is fully suppressed and 0 when the maximum response occurs for a uniform stimulus.

To map out the extent of classical and extra-classical receptive field regions, achromatic drifting gratings and uniform luminance stimuli were presented in variably sized apertures. Responses of $6 \mathrm{~K}$-on/off cells, $15 \mathrm{P}$ cells, and $14 \mathrm{M}$ cells to this stimulus set were successfully measured. Grating spatial frequencies were taken at or above each cell's preferred spatial frequency for large-aperture gratings, to stimulate selectively the classical (linear) center mechanism. The resulting responses were fit to a difference-of-Gaussians model (Sceniak et al., 1999; Solomon et al., 2002) of the following form:

$$
K=k_{c} \int_{-r}^{r} e^{-\left(y / r_{c}\right)} d y-k_{s} \int_{-r}^{r} e^{-\left(y / r_{s}\right)} d y .
$$

where the firing rate $K$ is a function of the strength of the excitatory (center) and suppressive (surround) Gaussian fields (given respectively by $K_{c}$ and $K_{s}$ ), and the radius of the excitatory and suppressive fields (given respectively by $r_{c}$ and $r_{s}$ ). Each stimulus subtends $r$ degrees of visual field, and the responses of excitatory and suppressive fields are integrated over the stimulus aperture for all $y$ such that $-r \leq y \leq r$. From the fitted curve we compute the surround suppression index:

$$
S S I=1-\frac{K_{u}}{K_{p}},
$$

where SSI is the surround suppression index, $K_{u}$ is the response to a full-field stimulus and $K_{p}$ is the peak response amplitude. The SSI measure is 1 when the response to a full-field stimulus is fully suppressed and 0 when the maximum response occurs for a stimulus of maximum size. Fits for two P cells and one K-on/off cell returned implausibly large center radii indicating that the stimulus was offset from the cells' receptive field center; these data were discarded.

Stationary achromatic gratings with sine-modulated contrast, also known as counterphase gratings (Enroth-Cugell and Robson, 1966; Hochstein and Shapley, 1976) were presented at variable spatial phase. Classically, this stimulus has been used to distinguish cells with linear and nonlinear spatial integration. For a linear (X-like) cell, there are two null phases where excitatory and inhibitory inputs to the cell are balanced, and the stimulus does not affect the cell's firing rate. Nonlinear (Y-like) cells instead show a frequency-doubled (f2) response across spatial phases, including at the nulls where the linear (f1) response is minimal. Measurements were made at optimal and twice-optimal spatial frequency for each cell.

To provide a simple descriptive model for cells' responses to counterphase gratings, we fit a rectified sine model to the responses. The equation follows that of Hochstein and Shapley (1976) and adds an expansive exponent term:

$$
K=k\left|\sin \left(\varphi-\varphi_{\text {null }}\right)\right|^{n}+b,
$$

where spike rate $K$ is a function of the gain $k$ for a stimulus at phase $\varphi$ relative to the "null phase" which provides the minimum response $\varphi_{\text {null }}$, raised to an exponent term $n$ and relative to a baseline rate $b$. Baseline, gain, and exponent were fit to each of f0, f1 and $\mathrm{f} 2$ independently; $\varphi_{\text {null }}$ was fitted to the three response harmonics simultaneously. The exponent term $n$ permits the model to fit a variety of spatial phase profiles. From this model, we calculated the nonlinearity index (Derrington and Lennie, 1984; White et al., 2001), defined as the average f2 response at all spatial phases divided by the $\mathrm{f} 1$ response at the optimum spatial phase.

It is obvious a priori that the responses of K-on/off cells are highly nonlinear. We therefore desired a simple nonlinear model which could encapsulate their responses to counterphase and drifting gratings. To do so, we developed a structural model of small, rectifying, Gaussian subunits which are spatially integrated across a larger Gaussian envelope. We hypothesize two fields of subunits, i.e., one field of on-rectified subunits and one field of off-rectified subunits. This model is illustrated in Figure 11.

The equation for a one-dimensional Gaussian kernel $G$ is as follows:

$$
G(x ; r)=\frac{1}{r \sqrt{2 \pi}} e^{-\left(\frac{x}{4 r}\right)^{2}},
$$

where the weight of the kernel at distance $x$ from its center is a function of the radius $r$ of the kernel and $e$ is the natural exponent. The contribution of the on-rectified subunit field is described (in one dimension) by the following:

$$
S U^{+}(x, t)=\max \left(0, V(x, t){ }^{\star} G\left(x ; r_{s u}\right)\right),
$$

where $S U^{+}(x, t)$ is the subunit response at position $x$ and time $t$. The spatiotemporal pattern of visual input $V(x, t)$ is convolved with the subunit Gaussian kernel $G$ with radius $r_{s u}$. For a counterphase grating, $V(x, t)=\cos (x) \cos (t)$; for a drifting grating, $V(x, t)=\cos (x+t)$. For the off-rectified subunit field, the sign of the rectification is reversed:

$$
S U^{-}(x, t)=\min \left(0, V(x, t){ }^{*} G\left(x ; r_{s u}\right)\right),
$$

The reader should note that in this model, the subunit(s) should not be thought of as discrete elements with independently variable size and spacing. Rather, a continuous field of subunits is hypothesized to contribute to the overall response of the cell. The overall response is given by a spatially weighted sum of the two subunit fields convolved with a Gaussian envelope (Fig. 11):

$$
\begin{aligned}
K(t)=\int_{-r}^{r} k^{+} S U^{+}(x, t-\Delta t) G\left(x-\Delta x ; r_{R F}\right) \partial x \\
\quad+\int_{-r}^{r} k^{-} S U^{-}(x, t-\Delta t) G\left(x-\Delta x ; r_{R F}\right) \partial x+b .
\end{aligned}
$$

In Equation 13, $K(t)$ is firing rate as a function of time, $r$ is the stimulus radius, $k^{+}$is the gain of the on-rectifying subunit $S U^{+}(x, t)$ (Eq. 11), $x$ is position (the variable of integration), $t$ is time, $\Delta t$ is the response latency, $G(x ; r)$ is the spatial profile of the Gaussian envelope (Eq. 10), $\Delta x$ is spatial offset relative to the stimulus center, $r_{R F}$ is the radius of the Gaussian 


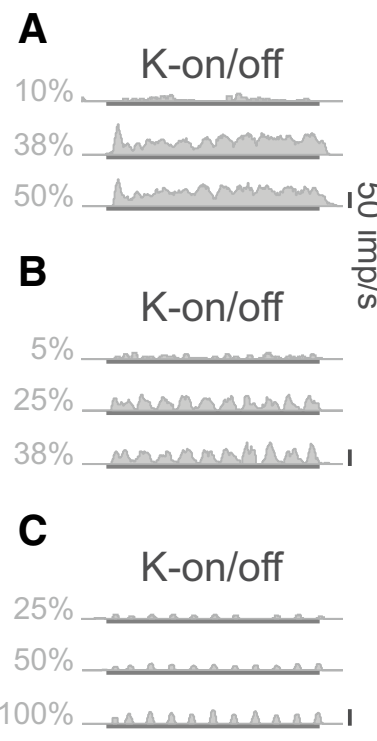

D

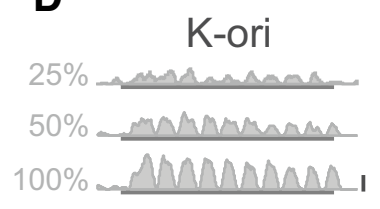

E
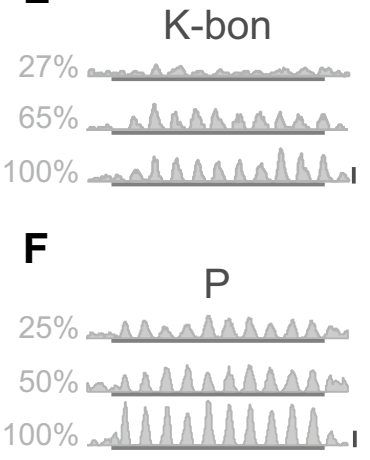

G

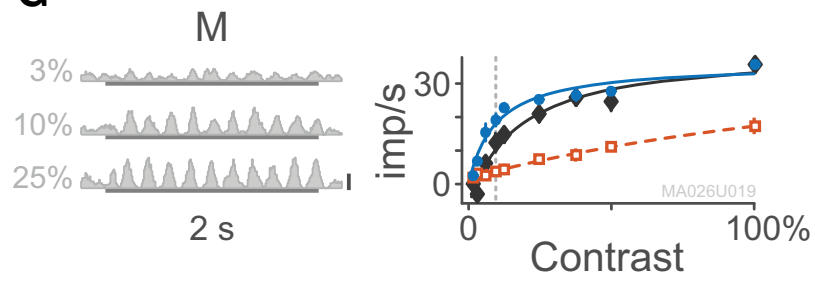

Figure 5. Example responses to drifting gratings of varying contrast. Example PSTHs are chosen relative to the $C_{50}$ contrast for each cell. Contrast response functions for the maintained firing and first two harmonics are shown at right; error bars, in many cases smaller than markers, give \pm SEM. Smooth curves show fits of the Naka-Rushton equation (Eq. 1) to the data. $\boldsymbol{A}-\boldsymbol{C}, \mathrm{K}$-on/off cells at $3.1^{\circ}, 12.8^{\circ}$, and $6.7^{\circ}$ eccentricity. $\boldsymbol{D}, \mathrm{K}$-ori cell at $2.6^{\circ}$ eccentricity. $\boldsymbol{E}$, K-bon cell at $4.0^{\circ}$ eccentricity response to modulation of $\mathrm{S}$-cone contrast. $\boldsymbol{F}, \mathrm{M}$-on cell at $4.8^{\circ}$ eccentricity. G, P-off cell at $24^{\circ}$ eccentricity. In all cases, the temporal frequency is $5 \mathrm{~Hz}$.

envelope, $k^{-}$is the gain of the off-rectifying subunit $S U^{-}$(Eq. 12), and $b$ is the tonic discharge rate. The model was implemented with seven free parameters: the overall gain $k^{+}$, the on/off linearity ratio $k^{+} / k^{-}$, the response latency (phase lag) $\Delta t$, spatial offset $\Delta x$, Gaussian envelope radius $r_{R F}$, the tonic discharge rate $b$ and the subunit radius $r_{s u}$, which is
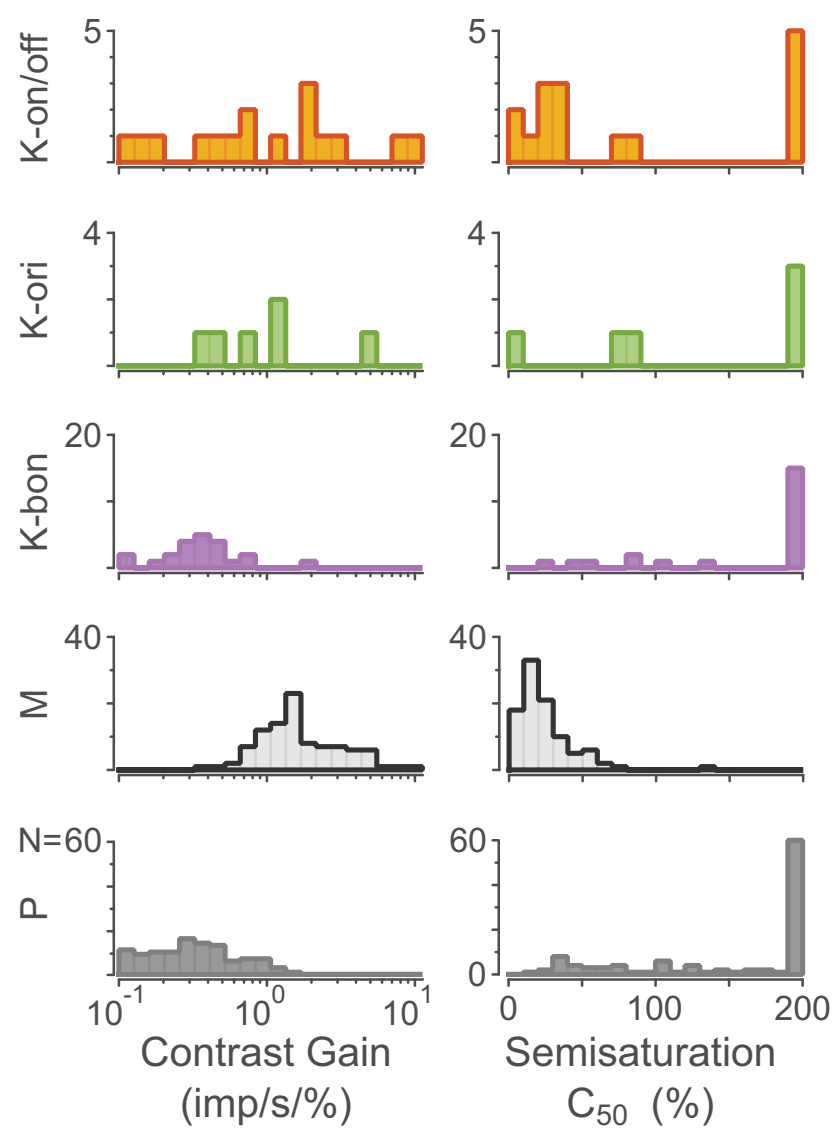

Figure 6. Distributions of fitted contrast gain and semisaturation $\mathrm{C}_{50}$ constant for K-on/off cells, K-ori cells, K-bon cells, M cells, and P cells. Linear cells had a fitted semisaturation constant of $200 \%$, yielding nearly straight-line fits as shown in Figure 5, C and $E$.

Table 3. Contrast sensitivity

\begin{tabular}{|c|c|c|c|c|}
\hline & Variable & Mean \pm SD & $\begin{array}{l}\text { Different } \\
\text { to K-on/off? }\end{array}$ & $\begin{array}{l}\text { Relationship } \\
\text { to eccentricity }\end{array}$ \\
\hline \multirow{2}{*}{$\begin{array}{l}\text { K-on/off } \\
\quad(n=17)\end{array}$} & $c_{50}, \%$ & $92.1 \pm 84.6$ & - & $r=-0.35, p=0.17$ \\
\hline & Gain, imp $/ \mathrm{s} / \%$ & $2.04 \pm 2.94$ & - & $r=+0.16, p=0.54$ \\
\hline \multirow[t]{2}{*}{ K-ori $(n=6)$} & $c_{50}, \%$ & $128.2 \pm 82.8$ & No $(p=0.80)$ & $r=-0.57, p=0.23$ \\
\hline & Gain, imp $/ \mathrm{s} / \%$ & 1.40 & No $(p=0.99)$ & $r=+0.92, p<0.01$ \\
\hline \multirow[t]{2}{*}{ K-bon $(n=22)$} & $c_{50}, \%$ & $160.5 \pm 62.7$ & $\operatorname{Yes}(p=0.02)$ & $r=-0.25, p=0.27$ \\
\hline & Gain, imp $/ \mathrm{s} / \%$ & $0.44 \pm 0.39$ & № $(p=0.06)$ & $r=+0.23, p=0.30$ \\
\hline \multirow[t]{2}{*}{$P(n=110)$} & $c_{50}, \%$ & $150.2 \pm 64.6$ & $\operatorname{Yes}(p=0.02)$ & $r=-0.16, p=0.09$ \\
\hline & Gain, in & $0.40 \pm 0.30$ & Yes $(p<0.01)$ & $r=-0.04, p=0.65$ \\
\hline \multirow[t]{2}{*}{$\mathrm{M}(n=100)$} & $c_{50}, \%$ & $24.9 \pm 19.4$ & $\operatorname{Yes}(p=0.04)$ & $r=-0.35, p<0.01$ \\
\hline & Gain, imp $/ \mathrm{s} / \%$ & $2.07 \pm 1.53$ & № $(p=0.09)$ & $r=+0.33, p<0.01$ \\
\hline
\end{tabular}

Fitted values for $c_{50}$ and gain from Equation 1 .

expressed relative to $r_{R F}$. The domain of integration in Equation 13 is limited to the stimulus radius $r$, as in Equation 7 .

The reader may at this point doubt whether a model with seven free parameters can yield meaningful insights into receptive field properties, but please note the model's key advantage. By performing the fit in the time domain, the model can predict mean discharge rate, first harmonic amplitude, and second harmonic amplitude across an arbitrary range of periodic visual stimuli. Here, we simultaneously fit the peristimulus time histograms (PSTHs) of responses to counterphase stimulation across spatial phases (for 2 spatial frequencies), as well as to the PSTHs of responses to full-field grating stimuli across spatial frequencies.

Fits were performed in MATLAB using constrained nonlinear leastsquares minimization. The model was fit to responses of $13 \mathrm{P}$ cells, $17 \mathrm{M}$ cells, and 8 on/off cells. For $\mathrm{P}$ and $\mathrm{M}$ cells the linearity ratio $\left(k^{+} / k^{-}\right)$ 
A
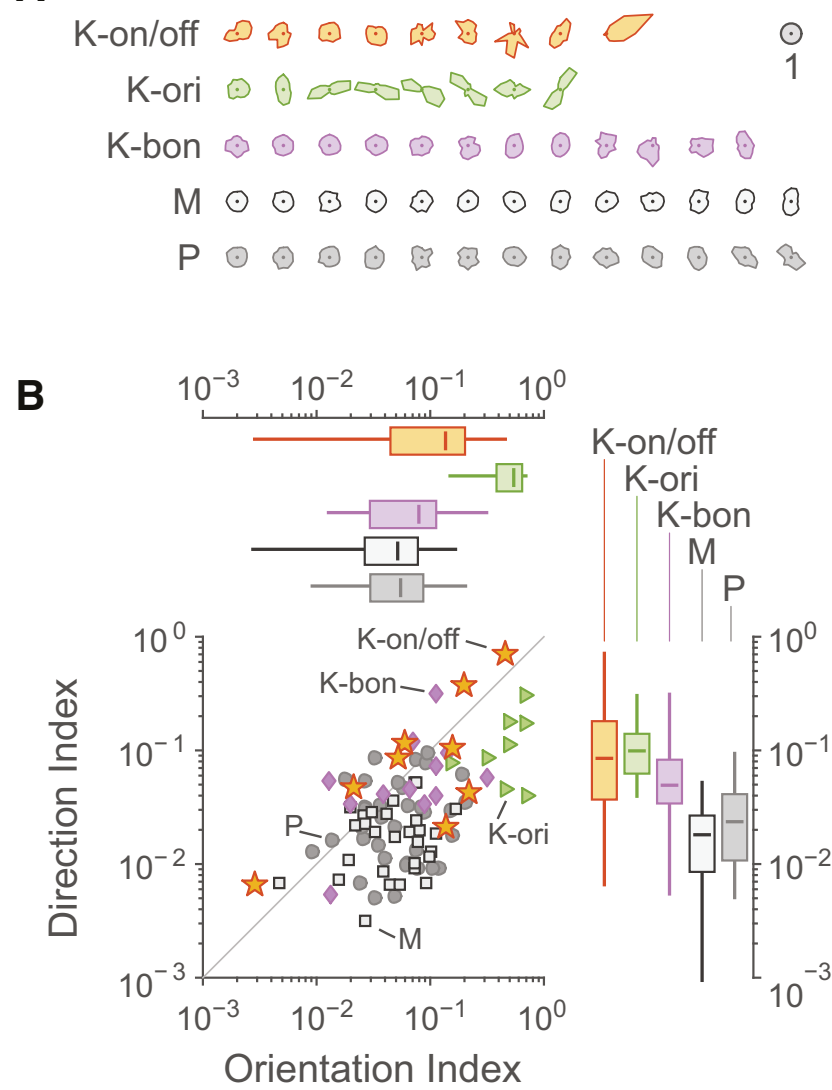

Figure 7. Direction and orientation tuning. A, Direction tuning curves for K-on/off cells, K-ori cells, K-bon cells, M cells, and P cells, arranged from least to most orientation-tuned. Curves are normalized such that each cell's average response is $1 . \boldsymbol{B}$, Distributions of direction and orientation selectivity indices. Box plots show median, range, and interquartile range.

normally lies between 1 (linear response around a maintained level) and 0 (half-wave rectified response). For on/off cells the linearity ratio lies between 0 and -1 , where -1 represents full-wave rectified response.

Experimental design and statistical analyses. Unless otherwise specified, statistics comparing cell classes use nonparametric Kruskal-Wallis tests and are corrected for multiple comparisons using Tukey's honest significant difference criterion. Paired data comparisons were conducted using Wilcoxon paired signed rank tests (and are identified as such), and crosstabular data were compared using standard $\chi^{2}$ tests. Unless otherwise specified, population means are stated \pm SD.

\section{Results}

\section{Identification and histological location of K-on/off cells}

Figure 1 shows typical response profiles of neurons in the marmoset LGN to small uniform $200 \mathrm{~ms}$ contrast pulses presented to the receptive field center; the response profiles are shown as PSTHs. Twelve K-on/off cells were identified using this stimulus, and five others were identified using $0.5 \mathrm{~Hz}$ square-wave contrast steps (data not shown). In all cases the $\mathrm{K}$-on/off cells respond transiently to onset and offset of contrast increments and decrements. Although variable, $\mathrm{K}$-on/off cells tend to have a low maintained firing rate (mean $4.9 \pm 6.5 \mathrm{imp} / \mathrm{s}$ ), which is marginally lower than that of K-bon cells $(11.4 \pm 9.7 \mathrm{imp} / \mathrm{s}, p=0.03)$ and $\mathrm{M}$ cells $(9.0 \pm 6.9 \mathrm{imp} / \mathrm{s}, p=0.09)$ and closer to that of $\mathrm{P}$ cells $(7.4 \pm 5.0 \mathrm{imp} / \mathrm{s}$, $p=0.31$ ). In common with $\mathrm{P}$ and $\mathrm{M}$ cells, $\mathrm{K}$-on/off cells are insensitive to S-cone-selective stimuli (Fig. 1, right column).

Figure 2 shows an example of a reconstructed electrode track through the LGN. Figure $2 A$ shows a NeuroTrace-stained coronal section through the LGN, $4.5 \mathrm{~mm}$ anterior (rostral) to the intra-aural line. Electrodes were coated in DiI to aid in the visualization of the electrode track, as described in Materials and Methods. Figure $2 B$ shows the reconstructed
Table 4. Orientation and direction selectivity

\begin{tabular}{lll}
\hline & OSI mean \pm SD & DSI mean \pm SD \\
\hline K-on/off $(n=9)$ & $0.15 \pm 0.14$ & $0.17 \pm 0.23$ \\
K-ori $(n=8)$ & $0.50 \pm 0.19$ & $0.12 \pm 0.08$ \\
K-bon $(n=12)$ & $0.09 \pm 0.08$ & $0.08 \pm 0.08$ \\
$\mathrm{P}(n=36)$ & $0.07 \pm 0.05$ & $0.03 \pm 0.02$ \\
$\mathrm{M}(n=30)$ & $0.06 \pm 0.04$ & $0.02 \pm 0.01$ \\
\hline
\end{tabular}

positions of two $\mathrm{P}$ cells and one on/off cell relative to the LGN recorded during the penetration shown in Figure $3 A$. The locations of 9 cells from 4 experiments which were histologically reconstructed in this way (including the 2 cells with incomplete physiological characterizations) are indicated schematically in Figure $2 C$, along with the approximate locations of the remaining 10 cells whose locations were estimated from physiological criteria and recording position in relation to cells recorded from the parvocellular and the magnocellular layers. For ease of comparison, data across all experiments are shown relative to a single LGN profile.

The on/off cells are predominantly located outside of the P or M layers, that is, in the $\mathrm{K}$ layers. For simplicity, in the following we name them K-on/off cells and consider them uniformly as part of the koniocellular/ interlaminar pathway(s); some anatomical inconsistencies notwithstanding. For example, the reconstructed cell position at coordinate AP3.5 (Fig. 2C) was within the internal M layer, but it had properties indistinguishable from those of other on/off cells which were clearly located in K layers. In such cases, or where the cell location could not be determined unambiguously, for statistical comparisons the cell was assigned to the nearest $\mathrm{K}$ layer (in this case, K3). Based on these combined histological and physiological criteria, five on/off cells were in the (ventral-most) koniocellular layer K1, five cells were in K2 (between the $\mathrm{M}$ layers), five cells were in layer $\mathrm{K} 3$ (between the $\mathrm{M}$ and $\mathrm{P}$ layers), and two cells were in layer K4 (between the internal and external parvocellular layers). We also observed neurons with on/off response profiles in the thalamic reticular nucleus (data not shown), and so cells which could not be definitively placed within the LGN were excluded from further analysis.

Approximately equal numbers of K-on/off cells were excited by stimuli presented via the ipsilateral (9/17) or contralateral (7/17) eyes; one cell had well matched binocular receptive fields (data not shown). As with $\mathrm{P}$ and $\mathrm{M}$ cells, eye dominance depended on the layer in which the cell was located $\left(\chi^{2}=13.28, p=0.04\right)$; each of the five on/off cells in layer K1 were excited by stimuli presented via by the contralateral eye whereas all but two cells in the other layers were dominated by the ipsilateral eye, as shown in Table 1. All results reported here are for monocular stimuli delivered through the dominant eye.

\section{K-on/off cells respond transiently}

We next characterized the temporal response properties of K-on/ off cells and compare them to those of P, M, and other K cells. The results are shown in Figures 3 and 4, and population summary statistics are given in Table 2. From Figure 3, it can be observed that K-on/off cells respond vigorously to both increments and decrements of ML-cone luminance, whereas $\mathrm{P}$ and $\mathrm{M}$ cells responses are suppressed to a level below the mean firing rate by anti-preferred stimuli. K-bon cells are excited by S-cone increments and ML-cone decrements, and suppressed by S-cone decrements and ML-cone increments. The on- and off-components of K-on/off cell responses appeared quite symmetric in amplitude (Fig. 3; Pearson's $r=0.77, p<0.01$; Table 2) and time course (Fig. 4B; Pearson's $r=0.78, p<0.01$; Table 2), with no significant difference in transience index (Fig. $4 D$; paired Wilcoxon $p=0.84$; Pearson's $r=-0.45, p=0.19$; Table 2).

Responses of K-on/off cells are highly transient: the population transience index for on/off cells $(0.98 \pm 0.09)$ is substantially greater than that of K-bon cells $(0.52 \pm 0.13)$ and P cells $(0.43 \pm$ 
A
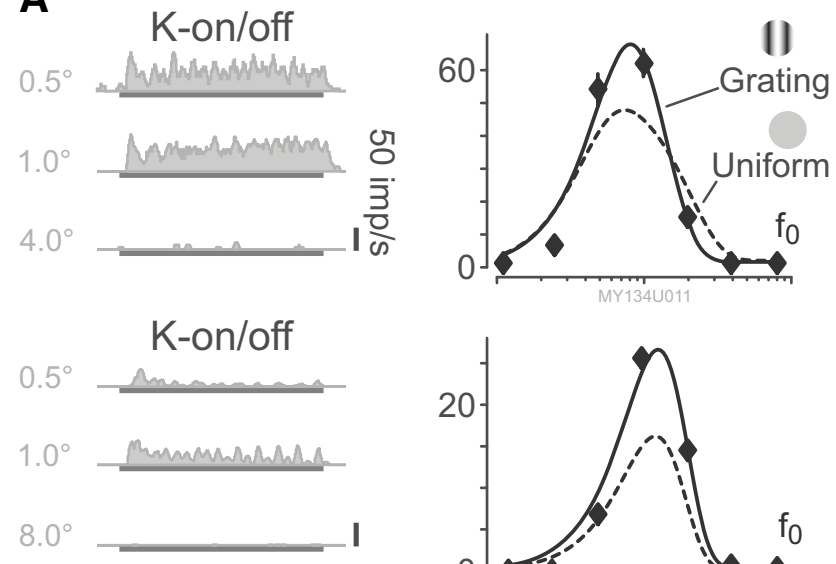

M
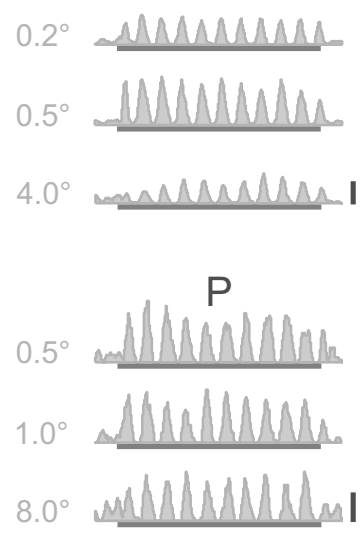

$2 \mathrm{~s}$
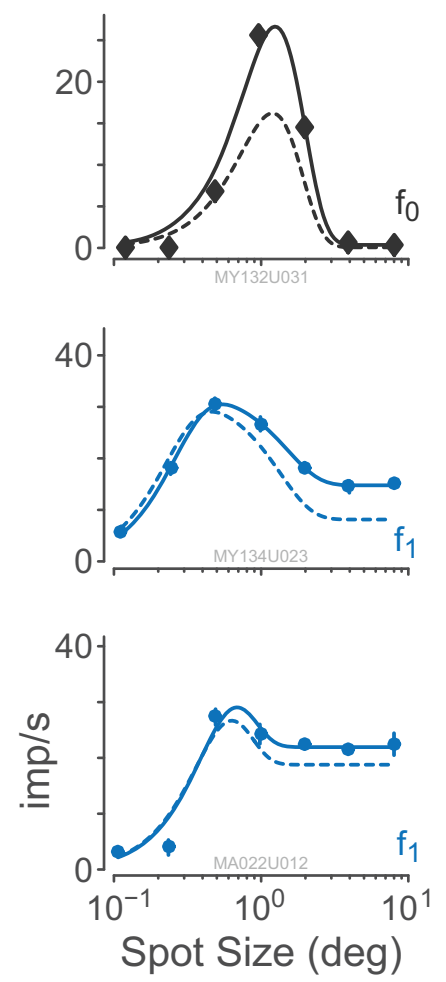

B

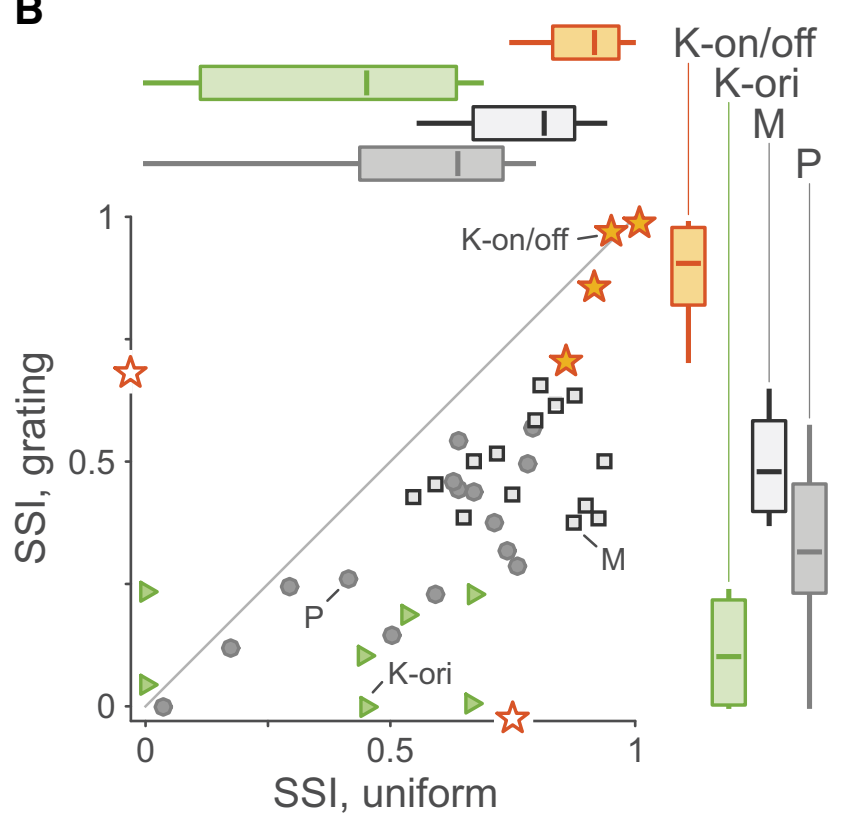

Figure 8. Responses to drifting gratings of varying aperture. $A$, Example PSTHs and aperture response curves for two K-on/off cells, an $\mathrm{M}$ cell, and a P cell. Example PSTHs are chosen relative to each cell's aperture of maximum response. The eccentricities of the cells are $3.1^{\circ}, 5.0^{\circ}, 6.5^{\circ}$, and $8.5^{\circ}$, respectively. Smooth curves show fitted difference-of-Gaussians functions as given by Equation 7. $\boldsymbol{B}$, Distributions of SSI for spatial uniform modulation and drifting grating stimuli.

Table 5. Classical and extraclassical surround suppression

\begin{tabular}{lllll}
\hline & Stimulus & $\begin{array}{l}\text { Excitatory field } \\
\text { radius, deg } \pm \text { SD }\end{array}$ & $\begin{array}{l}\text { Inhibitory field } \\
\text { radius, deg } \pm \text { SD }\end{array}$ & SSI \\
\hline K-on/off $(n=6)$ & Uniform & $0.29 \pm 0.16$ & $0.90 \pm 0.57$ & $0.86 \pm 0.13$ \\
& Grating & $0.27 \pm 0.10$ & $0.54 \pm 0.20$ & $0.85 \pm 0.13$ \\
K-ori $(n=7)$ & Uniform & $0.52 \pm 0.58$ & $3.55 \pm 4.90$ & $0.40 \pm 0.29$ \\
& Grating & $0.26 \pm 0.17$ & $5.14 \pm 4.37$ & $0.11 \pm 0.11$ \\
$\mathrm{P}(n=15)$ & Uniform & $0.16 \pm 0.09$ & $1.14 \pm 2.88$ & $0.56 \pm 0.24$ \\
& Grating & $0.15 \pm 0.09$ & $1.57 \pm 3.01$ & $0.33 \pm 0.17$ \\
$\mathrm{M}(n=14)$ & Uniform & $0.08 \pm 0.06$ & $0.43 \pm 0.31$ & $0.78 \pm 0.12$ \\
& Grating & $0.10 \pm 0.06$ & $0.42 \pm 0.31$ & $0.49 \pm 0.10$ \\
\hline
\end{tabular}

$0.32, p<0.01$ for both comparisons), and marginally greater that of $\mathrm{M}$ cells $(0.87 \pm 0.13, p=0.18)$. The mean response latency of $\mathrm{K}$-on/off cells is intermediate between that of $\mathrm{M}$ cells and that of K-bon and P cells (Table 2), but inspection of Figure 4 shows considerable spread; for example, one of the K-on/off cells responds at longer latency than any $\mathrm{M}$ or $\mathrm{P}$ cell in our sample, but others are in the range of low-latency $\mathrm{P}$ and $\mathrm{M}$ cell responses. In summary, we find the time course of K-on/off cell responses is very similar to that of $\mathrm{M}$ cells, but response latencies of $\mathrm{K}$-on/off cells have high variability.

\section{K-on/off cells show high contrast sensitivity}

The contrast response curves of individual cells are both useful for classifying cells in the LGN (Kaplan and Shapley, 1986) as well as for yielding insights into the functional role of different cell classes (Schiller et al., 1990). We found the saturating (nonexpansive) Naka-Rushton function (Eq. 1) provided a significantly better fit to the data than a linear model for $23.5 \%(4 / 17)$ of K-on/off cells and 83\% (83/100) of M cells but only $12.7 \%$ (14/ 110) of P cells. An expansive Naka-Rushton function (Eq. 2) provided a significantly better fit to the data than the nonexpansive Naka-Rushton function for only $17.6 \%$ (3/17) of Kon/off cells, 13\% (13/100) of M cells and 4.5\% (5/110) of P cells. Because the non-expansive Naka-Rushton function (Eq. 1) was the most parsimonious model, which could fit all cell classes, we compared the fitted parameter distributions for this model across all cells. Figure 5 shows the responses of three K-on/off cells (Fig. $5 A-C$ ), a K-ori cell (Fig. 5D), a typical K-bon cell (Fig. 5E), a typical $\mathrm{M}$ cell (Fig. $5 F$ ), and a typical P cell (Fig. $5 G$ ) to drifting gratings as the grating contrast was varied. The distributions of the fitted $c_{50}$ semisaturation constants and contrast gains for fits of Equation 1 are shown in Figure 6. The fitted values of $c_{50}$ for $\mathrm{K}$-on/off cells are lower than those of $\mathrm{P}$ cells $(p=0.02)$ and marginally higher than those of $\mathrm{M}$ cells $(p=0.04)$. Similarly, the contrast gain of K-on/off cells is higher than that of $\mathrm{P}$ cells $(p<$ $0.01)$ but close to that of $\mathrm{M}$ cells $(p=0.09)$. In summary, most $\mathrm{K}$-on/off cells in our sample showed high contrast sensitivity resembling or exceeding that of $M$ cells. Summary statistics are given in Table 3.

\section{K-on/off cells lack direction and orientation selectivity}

To investigate the relationship between the K-on/off cell population and the (rare) population of orientation-selective $\mathrm{K}$ cells previously described (Cheong et al., 2013), we measured the ori-

$\leftarrow$

Box plots show median, range, and interquartile range. Two K-on/off cells had only uniform or only grating data recorded; they are shown as open symbols on the relevant axis. K-on/off cells are more suppressed by large stimuli than $\mathrm{P}$ or $\mathrm{M}$ cells, and spatially uniform stimuli are more suppressive than drifting gratings. Temporal modulation frequency $5 \mathrm{~Hz}$. 
A
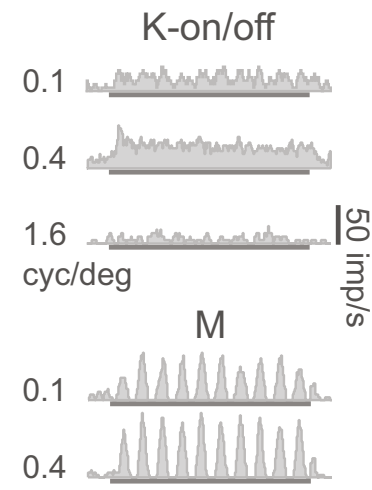

1.6 smangaratul cyc/deg

$P$

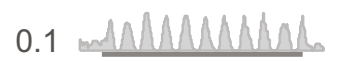

0.4 MWMMMM

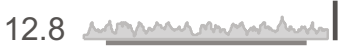

cyc/deg $2 \mathrm{~s}$
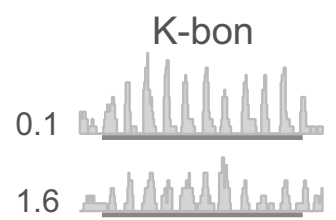

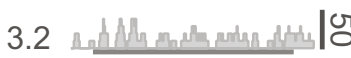
cyc/deg

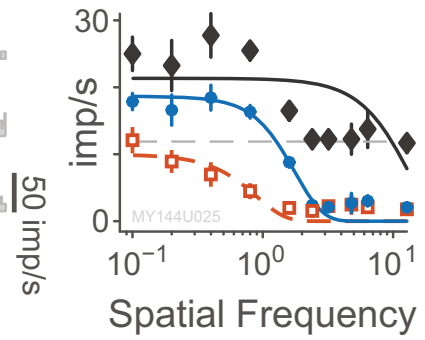

B

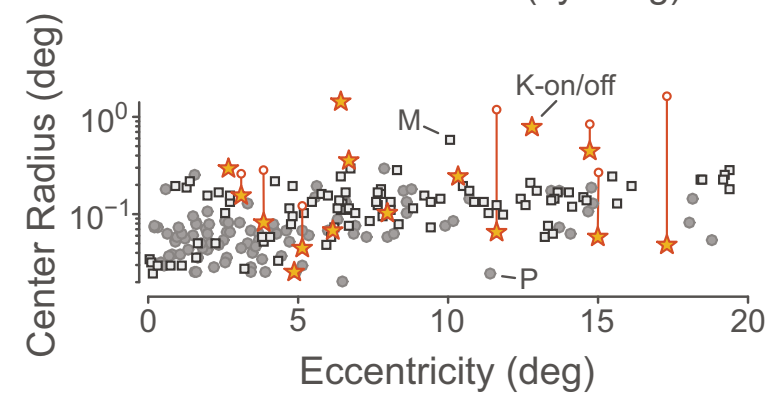

Figure 9. Responses to stimuli presented at different spatial frequencies. A, Example PSTHs and spatial frequency tuning curves for a K-on/off cell, an M-off cell, and a P-on cell, following the style of Figure 5. Example PSTHs are chosen relative to each cell's preferred spatial frequency. The eccentricities of the cells are $10.3^{\circ}, 18.5^{\circ}$, and $2.5^{\circ}$, respectively. Smooth curves show fitted difference-of-Gaussians functions as given by Equation 5. B. Distributions of fitted $\mathrm{RF}$ center radius relative to retinal eccentricity. Vertical lines and open circle symbols connect the center radius of K-on/off cells with the Gaussian envelope radius returned by the rectifying subunit model illustrated in Figure 11 and described in the text.

entation and direction selectivity of K-on/off cells and compared them to K-ori, K-bon, P, and M cells. With exception of two $\mathrm{K}$-on/off cells, none of the recorded cell populations showed direction-selectivity. Figure $7 A$ shows normalized direction tuning curves for K-on/off, K-ori, and K-bon cells, as well as a randomly selected subset of $\mathrm{P}$ and $\mathrm{M}$ cells, arranged from least to
A
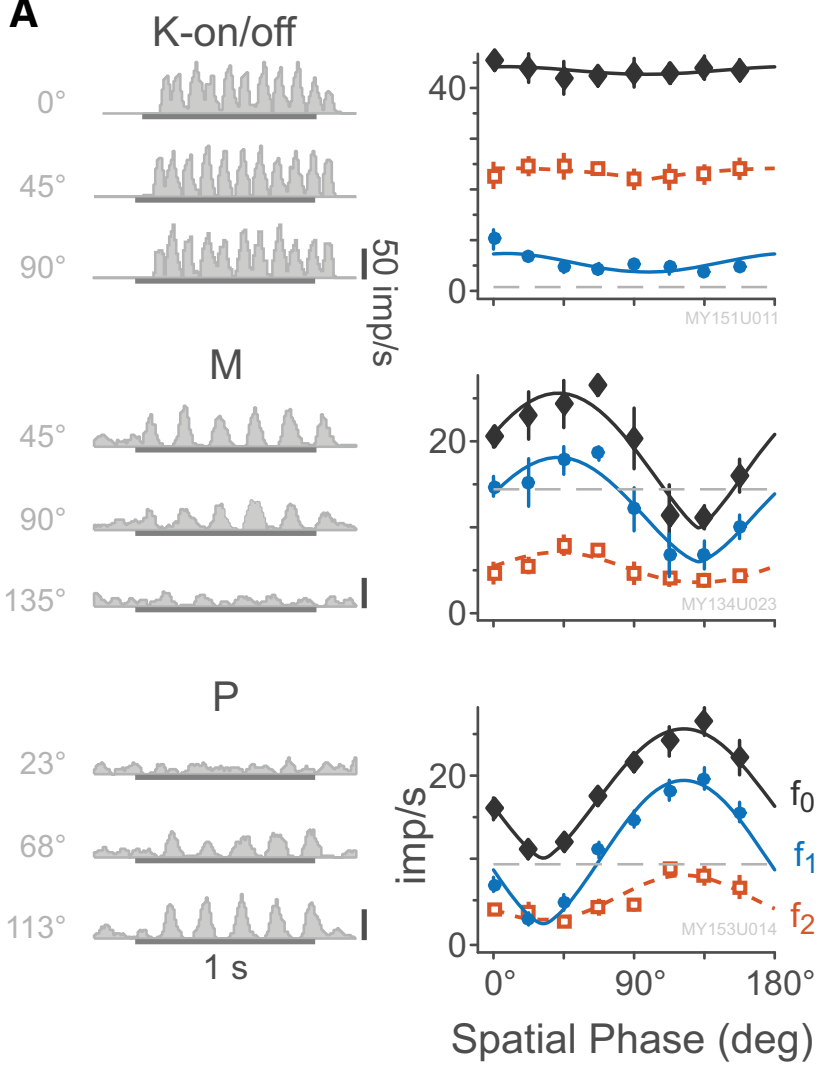

B

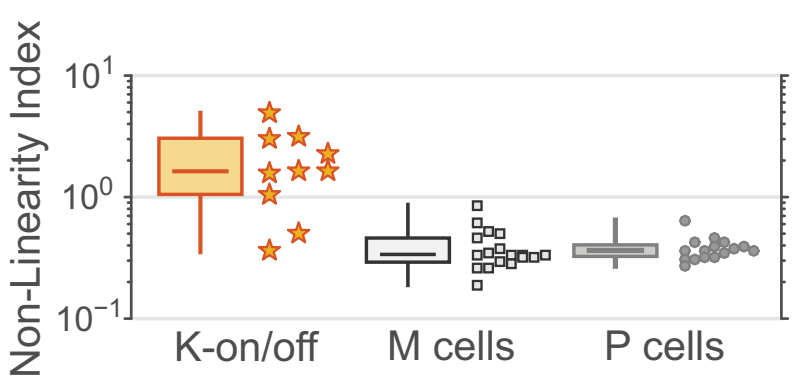

Figure 10. Responses to stationary counterphase stimuli. $A$, Example PSTHs and spatial phase sensitivity curves for a K-on/off cell, an M-on cell, and a P-off cell, following the style of Figure 5. Example PSTHs are chosen relative to each cell's preferred phase (top), null phase (bottom), and intermediate between those two. The eccentricities of the cells are $3.1^{\circ}, 6.5^{\circ}$, and $2.6^{\circ}$, respectively. Smooth curves show the fitted raised sine model as given by Equation $9 . \boldsymbol{B}$, Distributions of measured cell nonlinearity index. Box plots show median, range, and interquartile range. $\mathrm{K}$-on/off cells are more nonlinear than $\mathrm{P}$ or $\mathrm{M}$ cells.

most orientation-selective. Average direction and orientation selectivity indices are shown in Figure $7 B$ and Table 4. All three populations of $\mathrm{K}$ cell were significantly $(p=0.01)$ more direction selective than $\mathrm{M}$ cells but K-on/off cell direction selectivity was not different to the selectivity of the other $\mathrm{K}$ cell populations ( $p=0.77$ ), and was not statistically separated from that of P cells $(p=0.08)$. Unsurprisingly, K-ori cells showed higher orientation selectivity than every other recorded population $(p=0.01)$, as orientation selectivity is a primary classifying feature for these cells. The following point is important to note in this context. Our observations so far do not rule out the possibility that K-on/ off and K-ori cells constitute a single cell class which shows a continuum of orientation tuning. We return to this question in the following section; for now it does not affect our conclusion 


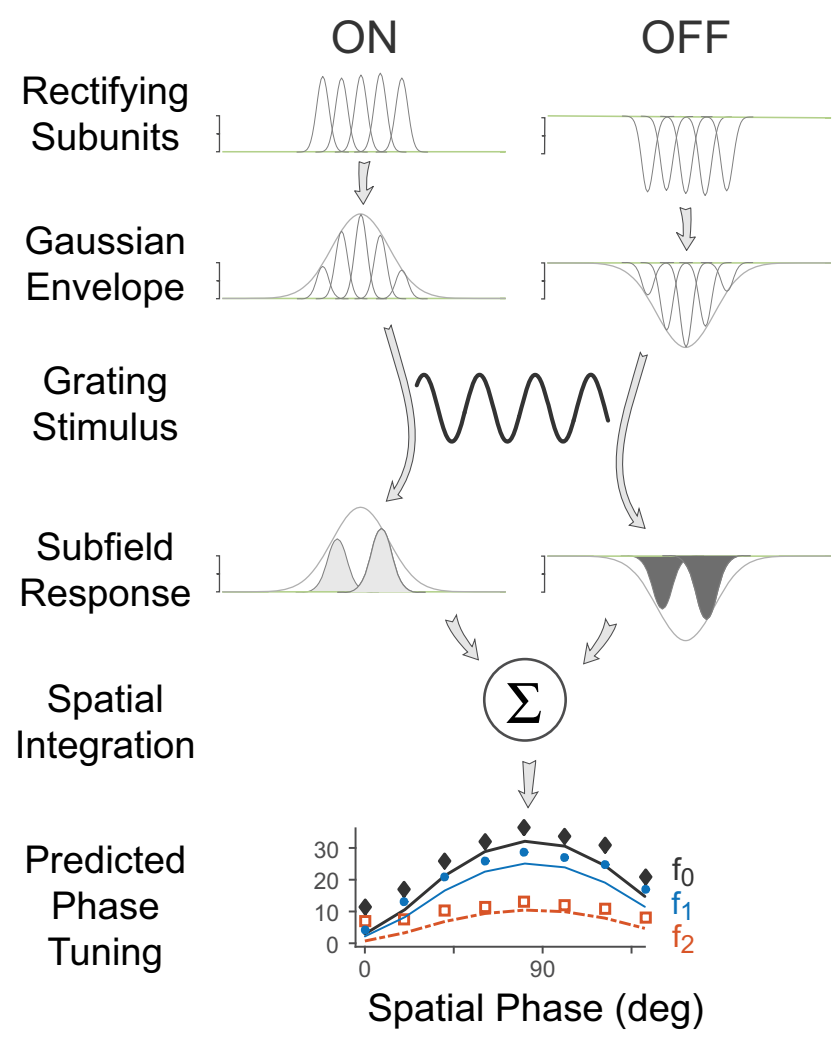

\section{Predicted \\ Frequency Tuning}

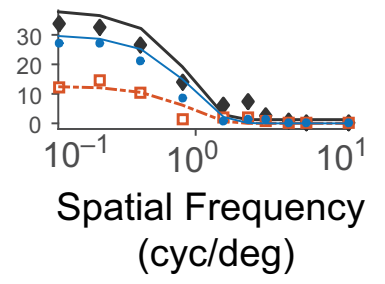

Figure 11. Schematic diagram of the rectifying subunit model which describes K-on/off cell receptive fields. Visual input is summed over a field of small Gaussian subunits, which are then rectified. This field of rectifying subunits is then integrated with a larger Gaussian envelope to fit the cell's overall response to the visual stimulus at each moment in time.

that that most K-on/off cells lack orientation or direction selectivity.

\section{K-on/off cells have strong suppressive surrounds}

Despite the lack of classical center/surround receptive field structure, K-on/off cells are strongly inhibited by stimuli larger than the classical receptive field. Profound suppression is evident for patches of grating at spatial frequencies above optimal (which do not activate the classic surround mechanism) as well as for modulated uniform fields. Figure $8 A$ shows example responses of two $\mathrm{K}$-on/off cells, an $\mathrm{M}$ cell, and a $\mathrm{P}$ cell to drifting gratings and uniform patches in variable apertures. The details of the aperture tuning properties of K-bon cells were published previously (Tailby et al., 2008). Grating and uniform patches returned similar estimates of excitatory and suppressive (inhibitory) spatial summation radius ( $p>0.37$, paired Wilcoxon), indicating strong extraclassical inhibitory inputs to K-on/off cells. Response amplitude of K-on/off was suppressed equally strongly by uniform patches and grating patches ( $p=0.69$, paired Wilcoxon). When measured using grating patches, K-on/off cells had stronger SSIs than $\mathrm{P}$ cells $(p<0.01)$ but not $\mathrm{M}$ cells $(p=0.12)$. The SSIs for K-on/off cells were also much higher than those of the
A
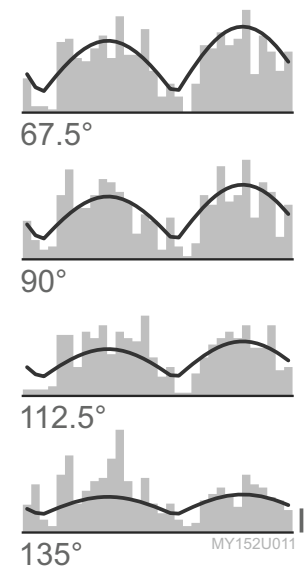

C

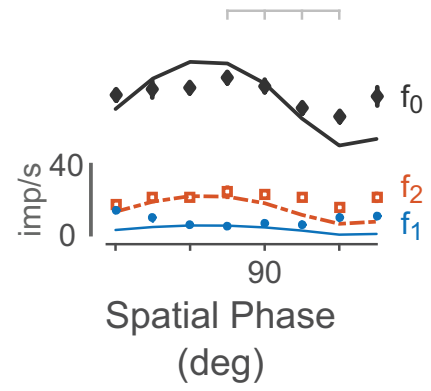

B
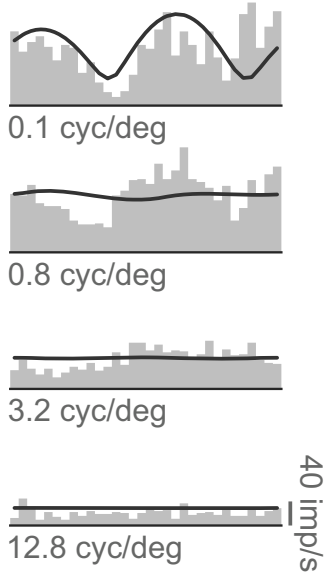

D

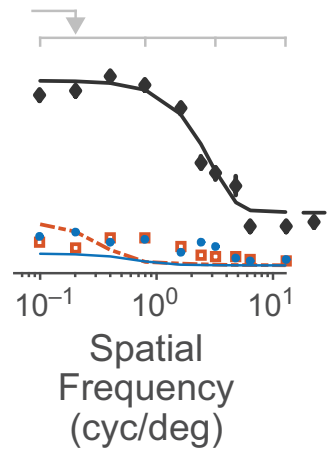

Figure 12. Example K-on/off response to counterphase and drifting grating stimuli. $\boldsymbol{A}, \mathrm{Ex}$ ample histograms of responses to counterphase stimulation at different spatial phases, folded to 1 cycle. Smooth line shows the fit of the rectifying subunit model at each point in time. Scale bar, $40 \mathrm{imp} / \mathrm{s}$. $\boldsymbol{B}$, Example histograms of responses to drifting gratings at different spatial frequencies. C, Predicted and measured responses to counterphase stimulation across spatial phases, following the style of Figure 5. The frequency-doubled $\mathrm{f} 2$ component is stronger than the linear f1 component at all spatial phases. Light gray marks indicate examples shown in A. D, Predicted and measured spatial frequency tuning curve. Light gray marks indicate examples shown in $\boldsymbol{B}$. The spatial frequency of the counterphase grating is indicated by an arrow. This cell is located at $11.6^{\circ}$ eccentricity. Note that the fitted model does not include terms for fitting the low-frequency (classical) surround.

small $(n=7)$ number of $\mathrm{K}$-ori receptive fields tested with this stimulus paradigm $(p<0.01)$. This result dissipates the possibility raised in the previous section, making it unlikely that K-on/off and K-ori cells constitute a single cell class, which shows a continuum of orientation tuning. The distribution of SSIs is shown in Figure $8 B$ and summary statistics for these data are given in Table 5. We conclude that K-on/off cells have strong suppressive surrounds which are activated by both grating and uniform stimuli. In this respect they differ from $\mathrm{P}$ and $\mathrm{M}$ cells as well as from $\mathrm{K}$-ori cells, providing further evidence that K-on/off cells form a distinct functional division of the koniocellular pathway in marmoset LGN.

\section{K-on/off cells show bandpass spatial tuning}

When the stimulus spatial frequency tuning was tested, K-on/off cells always showed elevated f0 response with a bandpass characteristic. An example K-on/off cell tuning curve, as well as curves for typical P, M, and K-bon cells are shown in Figure 9A. The observed center radius for K-on/off cell fo responses $\left(0.28^{\circ} \pm\right.$ $0.37^{\circ}$ ) was not significantly different to the observed center radius for linear $\mathrm{f} 1$ responses where present $\left(0.37^{\circ} \pm 0.39^{\circ}, p=0.5\right)$, nor 
were either f0 or $\mathrm{f} 1$ responses of K-on/off cells significantly different to the linear estimate for $\mathrm{M}$ cell centers $\left(0.14^{\circ} \pm 0.08^{\circ}\right.$, $p=0.94 \mathrm{vs}$ on/off f0 and $p=0.08 \mathrm{vs}$ on/ off $\mathrm{f} 1)$. On average the $\mathrm{P}$ cell center radii $\left(0.08^{\circ} \pm 0.05^{\circ}\right)$ were marginally smaller than all other cell classes $(p=0.02)$. Excluding cells that had negligible surround volume, the surround radii for the K-on/ off cell f0 response $\left(3.2^{\circ} \pm 2.8^{\circ}\right)$ were larger than the surrounds of either $\mathrm{M}$ cells $\left(1.1^{\circ} \pm 1.3^{\circ}, p=0.04\right)$ or $\mathrm{P}$ cells $\left(0.73^{\circ} \pm\right.$ $\left.0.67^{\circ}, p<0.01\right)$. The details of the spatial tuning properties of K-bon cells were published previously (Tailby et al., 2008; Eiber et al., 2018). Unlike P and M cells, the receptive field properties of K-on/off cells were not significantly correlated with eccentricity; Figure $9 B$ shows the relationship between center radius and eccentricity. In Figure 9B, for each K-on/off cell which was fit to the nonlinear model described below, the radius of the best-fit Gaussian envelope is also shown: the Gaussian envelope radius in all cases is larger than the center radius. In summary, $\mathrm{K}$-on/off cells have similar spatial frequency tuning to $\mathrm{M}$ and $\mathrm{P}$ cells but most $\mathrm{K}$-on/off cells are characterized by elevation in fo rather than stimulus-phaselocked responses. Together with the $\mathrm{K}$-on/off cell responses to counterphase gratings (described below), we can also conclude that the nonlinear f0 responses of K-on/off cells arise from subunits which have comparable radius to the receptive field radius of $\mathrm{P}$ or $\mathrm{M}$ cells.

\section{K-on/off cells show Y-like responses to counterphase gratings}

Responses to stationary counterphase gratings are a key tool for distinguishing nonlinear ("Y type") spatial summation (Enroth-Cugell and Robson, 1966; Kaplan and Shapley, 1982). The K-on/off cells responded to stationary counterphase gratings with elevated maintained firing and/or frequency-doubled response, which was largely independent of the spatial phase of the grating. Figure $10 \mathrm{~A}$ shows responses of a typical K-on/off cell, $\mathrm{M}$ cell, and $\mathrm{P}$ cell to counterphase stimulation: the K-on/off $\mathrm{f} 2$ is elevated above the $\mathrm{f} 1$ at all spatial phases, whereas the $\mathrm{P}$ and $\mathrm{M}$ cell both show clear null points at $30^{\circ}$ and $135^{\circ}$ spatial phase, respectively (cone-isolating counterphase stimuli were not presented to K-bon cells). Population data are shown in Figure 10B. The nonlinearity index of the $\mathrm{K}$-on/off cells $(2.55 \pm 1.55)$ was significantly greater than that of either M cells $(0.59 \pm 0.19, p<0.01)$ or P cells $(0.64 \pm 0.17, p<$ 0.01 ). These data reinforce our previous observation (White et al., 2001) that in marmosets receptive fields showing Y-type spatial summation are segregated to the K layers.

\section{Structural model for K-on/off receptive fields}

Figure 11 is an illustration of the rectified subunit model of Equaiton 13, which explains the observed responses of K-on/off cells to counterphase and drifting grating stimuli. Figure 12
B

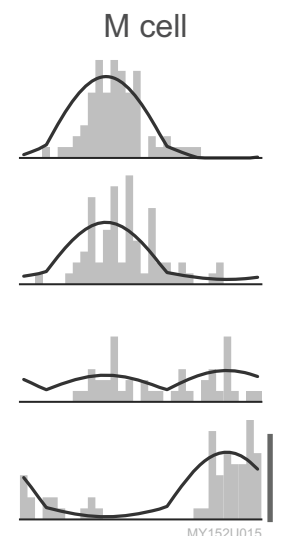

E

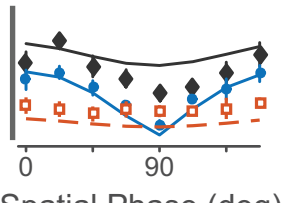

Spatial Phase (deg)

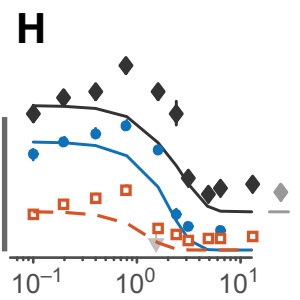

Spatial Frequency (cyc/deg)

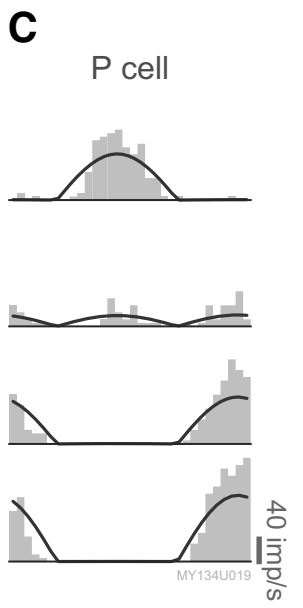

$\mathbf{F}$

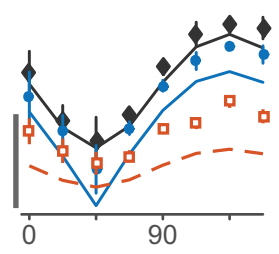

I

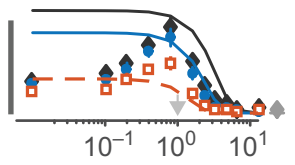

Figure 13. Example predictions and responses to counterphase stimuli, following the style of Figure $12 . \boldsymbol{A}, \mathrm{K}$-on/off cell $\left(17.3^{\circ}\right.$ eccentricity). $\boldsymbol{B}, \mathrm{M}$ on cell $\left(9.4^{\circ}\right.$ eccentricity). $\boldsymbol{C}, \boldsymbol{P}$ off cell $\left(8.5^{\circ}\right.$ eccentricity). $\boldsymbol{D}-\boldsymbol{F}$, Predicted and measured responses to counter列 cale bars, $20 \mathrm{imp} / \mathrm{s}$. G-I, Predicted and measured spatial frequency tuning curves for the cells shown in $\boldsymbol{A}-\boldsymbol{C}$. The spatial frequency of the counterphase gratings are indicated by arrows.

shows an example of a fitted K-on/off cell response to counterphase gratings at various spatial phases (Fig. $12 \mathrm{~A}, \mathrm{C}$ ) as well as drifting gratings at various spatial frequencies (Fig. $12 \mathrm{~B}, \mathrm{D}$ ). A single set of parameters was used to predict the observed $\mathrm{f} 0, \mathrm{fl}$, and $\mathrm{f} 2$ responses across both drifting and counterphase stimuli. Figure 13 shows fits to responses of a typical K-on/off cell, M cell, and $\mathrm{P}$ cell (this model was not fit to responses from K-bon cells). The rectified subunit model captures the main nonlinear features of K-on/off cell responses (Fig. 13A), including the highfrequency component of the spatial frequency tuning curves and the frequency-doubled responses to counterphase gratings. Substantial features of the M cell (Fig. 13B) and P cell responses (Fig. $13 C$ ) are also captured by the model. Because the model is based on excitatory rectified inputs, it does not capture the lowfrequency (classical surround) limb of the spatial tuning curves (Fig. 13I). These points however make up a small proportion of the fitted data for each cell and were not found to strongly bias the fit parameters, and so for simplicity they were not excluded from the measurement base.

Two interesting results, shown in Figure 14, emerged from the distribution of fitted parameters of the rectified subunit model. 


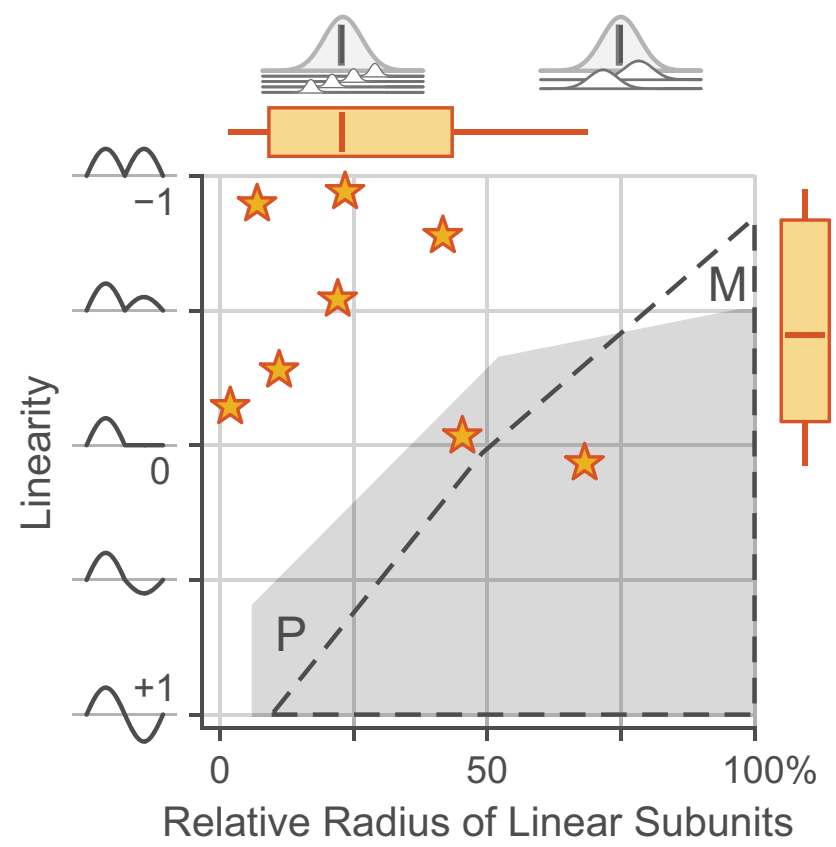

Figure 14. Comparison of linearity index and relative subunit radius for K-on/off cells. The region in which fitted values for $P$ and $M$ cells fall are indicated. Box plots show median, range, and interquartile range. The interpretations of the two parameter measures are illustrated at left and above the graph.

Table 6. Rectifying subunit model fit parameters

\begin{tabular}{lrll}
\hline & $\begin{array}{l}\text { Linearity ratio, } \\
\text { mean } \pm \text { SD }\end{array}$ & $\begin{array}{l}\text { Rectifying subunit } \\
\text { radius, rsu deg } \pm \text { SD }\end{array}$ & $\begin{array}{l}\text { Gaussian envelope } \\
\text { radius, rRF deg } \pm \text { SD }\end{array}$ \\
\hline K-on/off $(n=8)$ & $-0.44 \pm 0.40$ & $0.09 \pm 0.06$ & $0.56 \pm 0.51$ \\
P cells $(n=13)$ & $0.33 \pm 0.46$ & $0.03 \pm 0.02$ & $0.08 \pm 0.07$ \\
M cells $(n=17)$ & $0.26 \pm 0.52$ & $0.08 \pm 0.05$ & $0.14 \pm 0.11$ \\
\hline
\end{tabular}

First, for K-on/off cells the rectifying subunit radius was typically $\sim 25 \%$ of the Gaussian envelope radius. This result suggests that the excitatory summation field fit from aperture tuning curves (Fig. 8) reflects the integrating field of K-on/off cells (i.e., the Gaussian envelope radius), whereas the center radius fit from spatial frequency tuning better reflects the rectifying subunit radius. For the small number of K-on/off cells where recordings were held for long enough to measure aperture tuning, linearity, and spatial frequency tuning $(n=4)$, the relevant parameters were indeed correlated as suggested (aperture excitation radius: Gaussian envelope radius $r^{2}=0.93, p=0.03$; spatial frequency tuning center radius: rectifying subunit radius $r^{2}=0.97$, $p=0.01$ ), but a larger dataset would be required to draw firm conclusions. Second, although the K-on/off Gaussian envelope radius was marginally larger than either the envelope or the rectifying subfield radius for $\mathrm{P}$ or $\mathrm{M}$ cells $(p=0.04)$, the K-on/off rectifying subfields had comparable radius to that of $\mathrm{M}$ and $\mathrm{P}$ cells ( $p>0.2$ for both comparisons). As expected, the K-on/off cell linearity index (mean $-0.44 \pm 0.40$ ) is significantly different from that of $\mathrm{P}$ cells $(p<0.01)$ or M cells $(p<0.01)$. Two of the $\mathrm{K}$-on/off cells fall within the envelope of $\mathrm{P}$ and $\mathrm{M}$ cells in Figure 14. These cells (observations MY154.19 and MY153.24) also showed signs of relatively linear spatial summation on other measures (e.g., low nonlinearity index). Other properties of these cells however were within the range of other K-on/off cells. Population averages for linearity index, as well as the radii of the rectifying subunits and the Gaussian integrating envelope are presented in Table 6.

\section{Summary of results}

Table 7 presents key receptive field parameters measured across our recorded population of K-on/off cells. To summarize, K-on/ off cells receptive fields show $\mathrm{M}$-like contrast sensitivity and substantial spatial nonlinearity. They show complex-like $(\mathrm{f} 0>\mathrm{f} 1$ ) responses to drifting gratings and Y-like frequency-doubled $(\mathrm{f} 2>\mathrm{f} 1)$ responses to counterphase gratings. Unlike responses of $\mathrm{P}$ or $\mathrm{M}$ cells, responses of K-on/off cells are best described as a weighted spatial summation of full-wave-rectified visual inputs within the receptive field.

\section{Discussion}

\section{Response properties and cross-species homology of K-on/off cells}

We here provide the largest sample of on/off cells recorded to our knowledge in any primate to date. Many response properties of $\mathrm{K}$-on/off cells are distinct from those of $\mathrm{P}$ or $\mathrm{M}$ cells, as well as those of other described subpopulations of $\mathrm{K}$ cells. We more frequently encountered $\mathrm{K}$-on/off cells in ventral $\mathrm{K}$ layers than in the more dorsal layers, adding to our previous evidence for some anatomical segregation of distinct functional subgroups of K cells to different K layers (White et al., 2001; Percival et al., 2014). The $\mathrm{K}$-on/off cells in layers $\mathrm{K} 1$ and $\mathrm{K} 3$ show higher contrast sensitivity than that of K-on/off cells in layers K2 and K4. Our sample $(n=17)$ of K-on/off cells is not large enough to rule out the possibility there exist discrete subpopulations of K-on/off cells with distinct properties. Nevertheless we can safely conclude that $\mathrm{K}$-on/off cells have contrast responses which are more M-like than P-like.

The receptive field of K-on/off cells consists of spatially coextensive on and off discharge fields, and they have strong suppressive surrounds (Fig. 8). These properties are similar to those of the local-edge-detector cells described in rabbit (Levick, 1967; van Wyk et al., 2006) and local-edge-detector/impressed-bycontrast (LED/IBC) receptive fields in cat retina (Cleland and Levick, 1974; Troy et al., 1989). But unlike LED/IBC cells (which show sustained responses to contrast steps) the K-on/off cells we recorded all showed by Sivyer et al. (2011) transient responses to contrast steps (Figs. 1, 3, and 4). In this respect they more resemble the on/off phasic cells in rat's LGN (Fukuda et al., 1979), the transiently responding "UHD" on/off retinal ganglion cells in mouse retina (Jacoby and Schwartz, 2017), or the transient ONOFF cells in rabbit retina (Sivyer et al., 2011). Other properties of transient ON-OFF cells in rabbits do show overlap with those of LED/IBC cells (and, as pointed out, the two types may have been confused in earlier reports: Sivyer et al., 2011). This problem notwithstanding, properties of transient ON-OFF cells in rabbit retina remain a good match for the K-on/off cells that we found here in marmoset LGN.

The K-on/off cells we characterize here do clearly have properties in common with "type $\mathrm{Vb}$ " on/off ganglion cells recorded $>40$ years ago in macaque retina by de Monasterio (1978). His type $\mathrm{Vb}$ cells show transient on/off responses, have a strong suppressive surround, lack input from S cones, and show frequencydoubled responses to counterphase contrast modulation (de Monasterio, 1978, his Figs. 5, 7). The type Vb on/off ganglion cells could be antidromically activated from the LGN and/or superior colliculus. An example of a collicular-projecting on/off receptive field with strong suppressive surround is also shown by Schiller and Malpeli (1977, their Fig. 12). These sparse examples from the past literature support the view that on/off receptive fields are an integral part of the retinogeniculate and retinocollicular pathways in primates. 
Table 7. summary of K-on/off cell tuning properties

\begin{tabular}{|c|c|c|c|c|c|c|c|c|c|c|c|}
\hline$\overline{I D}$ & $\mathrm{ECC}$ & LAY & F1:F0 & C50\% & SFI & SSI & OSI & RRF & RSU & LIN & $\overline{\mathrm{NLI}}$ \\
\hline MY132.31 & 5.0 & (K4) & 0.85 & $>100$ & - & 1.00 & - & - & - & - & - \\
\hline MY142.06 & 6.2 & (K4) & 0.60 & $>100$ & 0.34 & - & - & - & - & - & - \\
\hline MA0030 & 15.0 & (K3) & 0.43 & 83.2 & 0.66 & 0.92 & 0.22 & 0.24 & 0.05 & -0.55 & 1.59 \\
\hline MY154.04 & 14.7 & K3 & 0.26 & 39.1 & 0.51 & - & 0.05 & 0.78 & 0.18 & -0.94 & 1.62 \\
\hline MY154.19 & 5.1 & K3 & 0.01 & 14.7 & 0.21 & - & - & 0.12 & 0.05 & -0.03 & 0.51 \\
\hline MY134.11 & 3.1 & (K3) & 0.18 & 33.5 & 0.00 & 0.96 & 0.06 & 0.21 & 0.09 & -0.78 & 4.89 \\
\hline MY151.11 & 3.1 & K3 & 0.15 & 29.4 & 0.22 & - & 0.16 & - & - & - & 3.18 \\
\hline MY144.21 & 6.7 & (K2) & 0.88 & $>100$ & 0.58 & 0.86 & - & - & - & - & - \\
\hline MY153.19 & 3.8 & K2 & 0.29 & $>100$ & 0.00 & - & - & 0.28 & 0.03 & -0.28 & 1.05 \\
\hline MY153.20 & 4.9 & K2 & 0.85 & $>100$ & 0.32 & - & - & - & - & - & - \\
\hline MY135.13 & 6.4 & (K2) & 0.68 & $>100$ & 0.00 & - & 0.02 & - & - & - & 1.64 \\
\hline MA003s & 17.3 & (K2) & 0.27 & 3.7 & 0.00 & - & 0.14 & 1.50 & 0.03 & -0.14 & 3.05 \\
\hline MA008 $\mathrm{h}$ & 12.8 & (K1) & 0.38 & 21.5 & 0.63 & 1.00 & 0.46 & - & - & - & - \\
\hline MY141.29 & 8.0 & (K1) & 0.87 & 35.4 & 0.37 & - & 0.20 & - & - & - & - \\
\hline MY141.30 & 10.3 & (K1) & 0.19 & 21.2 & 0.58 & - & - & - & - & - & - \\
\hline MY153.24 & 29.1 & K1 & 0.83 & 76.0 & - & 0.76 & - & 0.25 & 0.17 & 0.07 & 0.36 \\
\hline MY152.11 & 11.6 & K1 & 0.25 & 8.4 & 0.00 & - & 0.00 & 1.09 & 0.08 & -0.89 & 2.25 \\
\hline
\end{tabular}

$\mathrm{C50}$, Naka-Rushton semisaturation constant; ECC, receptive field eccentricity (deg); F1:F0, Fourier harmonic ratio; ID, cell identifier; LAY, koniocellular layer (cells whose locations were estimated from physiological and stereotaxic data are indicated in parentheses); LIN, linearity ratio; NLI, non-linearity index; RRF, Gaussian envelope radius $\left(r_{R F}\right.$ deg.); $S S I$, surround suppression index; OSI, orientation selectivity index; RSU, rectifying subunit radius $\left(r_{\text {sur }}\right.$ deg); $S F I$, spatial frequency selectivity index. Parameters that were not determined are marked with a dash.

\section{Potential retinal inputs to K-on/off cells}

Broad-thorny cells are conspicuous among wide-field ganglion cells projecting to LGN and colliculus in macaque (Dacey et al., 2003) and marmoset (Szmajda et al., 2008) monkeys; making them a potential source of retinal input to K-on/off cells in LGN. Recent recordings from these cells in macaque retina (Puller et al., 2015) revealed two properties consistent with those of our K-on/off cells: specifically, broad-thorny cells showed transient on/off responses to maintained contrast, and strong suppressive surrounds. The authors did not measure contrast dependence or spatial linearity of broad-thorny cells, reducing the security of the correspondence; nevertheless the following observations suggest that, by elimination, broad-thorny cells make a good candidate source of retinal inputs to K-on/off cells.

Smooth monostratified ganglion cells in macaque and marmoset retina project to the LGN (Crook et al., 2008; Masri et al., 2016), show M-like contrast sensitivity and Y-like spatial nonlinearity, and lack input from S cones (Crook et al., 2008). But unlike K-on/off cells, smooth monostratified cells show unipolar (on- or off-type) responses to drifting gratings, and conventional center-surround antagonistic receptive field structure. The transient, Y-like upsilon cells characterized in massive parallel recordings from macaque retina (Petrusca et al., 2007) likewise show unipolar responses to maintained contrast. One could imagine selective convergent input from on-off pairs of these ganglion cell types to K-on/off cells in LGN, but this seems less likely given the well matched amplitude and time course of the on-polarity and off-polarity responses of K-on/off cells (Fig. 4).

In addition to broad-thorny cells, at least four other retinal ganglion cells types (small bistratified, large bistratified, recursive bistratified, and multi-tufted) stratify across both the on- and off-lamina of the inner plexiform layer in macaque and marmoset monkeys (Dacey, 2004; Yamada et al., 2005; Masri et al., 2016). The small bistratified and large bistratified cells can be ruled out as retinal inputs to K-on/off cells. Recordings from these cells in macaque retina reveal strong $S$ cone input (for review, see Dacey, 2004), but none of our K-on/off cells showed substantial input from $S$ cones. Limited recordings from recursive bistratified cells (Puller et al., 2015) revealed transient, on/off responses, but little further information about recursive bistratified cells or multi-tufted cells is known. These observations favor broad-thorny cells as a likely source of retinal input to K-on/off cells.

\section{Non-retinal visual inputs to K-on/off cells}

In macaque monkeys, the main retino-recipient nucleus in the midbrain, the superior colliculus (SC), is known to receive direct input from on/off ganglion cells (Schiller and Malpeli, 1977; de Monasterio, 1978), and on/off responses are commonly observed in recordings from retino-recipient layers of macaque SC (Cynader and Berman, 1972; Schiller et al., 1974) and marmoset SC (Tailby et al., 2012). Furthermore, in adult macaque monkeys, neurons in area MT/V5 lose visual responsivity after combined lesions to ipsilateral SC and V1 (Rodman et al., 1990). Together with anatomical evidence that there is a retinotopically organized projection from the superficial (retino-recipient) SC layers to the K layers of the LGN (Harting et al., 1978; Stepniewska et al., 2000; Zeater et al., 2018), these findings make it possible that the K-on/ off cells we have observed here are recipients of collicular, rather than (or additional to) retinal innervation. Indeed, K-on/off cells were more likely to be observed in the more ventral $\mathrm{K}$ layers, which agrees with the observed pattern of projections from SC to LGN. Cortical inputs to the LGN are a second potential contributor but unlike driving input from retina (and, potentially, colliculus) the cortical inputs are believed to modulate rather than strongly drive LGN relay cell excitability (Sincich et al., 2007).

\section{Relevance for visual processing}

What relevance could K-on/off cells have for visual perception? These cells are highly nonlinear, and we speculate that they play a role carrying a Y-like signal in primates. It has been proposed that Y-like signals can contribute to the processing of information about moving objects (Demb et al., 2001b; Gollisch and Meister, 2010). The highly transient nature and short visual latency of K-on/off cells (Fig. 4; Table 2) are also consistent with contribution to detection of rapid movement. There thus may be a role for $\mathrm{K}$-on/off cells in motion-processing pathways projecting to the cortical dorsal visual processing stream, including direct projections from LGN to area MT (Stepniewska et al., 2000; Sincich et al., 2004; Warner et al., 2010). The K-on/off cells were segregated to the ventral $\mathrm{K}$ layers, where the direct MT/V5 projecting cells are also segregated in macaques (Sincich et al., 2004) and mar- 
mosets (Warner et al., 2010). Of course, projections of K-on/off cells to V1 are also possible. Local edge detectors in the LGN of cat (Cleland et al., 1976) as well as on/off phasic cells in the LGN of the rat (Fukuda et al., 1979) can be antidromically activated by electrodes inserted in the primary visual cortices.

Here, we did not directly demonstrate projection of K-on/off cells to extrastriate cortices (specifically MT/V5), but some of their functional properties make them potential candidates to contribute to this pathway, and therefore potential contributors to the residual visual functions that survive damage to V1. Relevant functional evidence is, however, ambiguous. On one hand, following lesions to V1 in early life, residual responses in marmoset MT/V5 typically show on/off responses with negligible direction selectivity (Yu et al., 2013, their Fig. 1), consistent with the properties of K-on/off cells. On the other hand, direction selectivity is not abolished following acute lesions or transient inactivation of V1 (Rodman et al., 1989; Girard et al., 1992; Rosa et al., 2000), and K-on/off cells do not show direction selectivity, which is the hallmark of MT/V5 responses. As suggested by Yu et al. (2013) it is possible that direct inputs from LGN to MT/V5 play a priming role during development to establish basic visual responses, whereas selectivity for motion is later imprinted by dominant inputs from V1.

\section{References}

Brainard DH (1996) Cone contrast and opponent modulation color spaces. In: Human color vision (Kaiser PK, Boynton GM, eds), pp 563-577. Washington, DC: Optical Society of America.

Casagrande VA (1994) A third parallel visual pathway to primate area V1. Trends Neurosci 17:305-310. CrossRef Medline

Cheong SK, Tailby C, Solomon SG, Martin PR (2013) Cortical-like receptive fields in the lateral geniculate nucleus of marmoset monkeys. J Neurosci 33:6864-6876. CrossRef Medline

Cleland BG, Levick WR (1974) Properties of rarely encountered types of ganglion cells in the cat's retina and an overall classification. J Physiol 240:457-492. CrossRef Medline

Cleland BG, Levick WR, Morstyn R, Wagner HG (1976) Lateral geniculate relay of slowly-conducting retinal afferents to cat visual cortex. J Physiol 255:299-320. CrossRef Medline

Crook JD, Peterson BB, Packer OS, Robinson FR, Gamlin PD, Troy JB, Dacey DM (2008) The smooth monostratified ganglion cell: evidence for spatial diversity in the Y-cell pathway to the lateral geniculate nucleus and superior colliculus in the macaque monkey. J Neurosci 28:12654-12671. CrossRef Medline

Cynader M, Berman N (1972) Receptive-field organization of monkey superior colliculus. J Neurophysiol 35:187-201. CrossRef Medline

Dacey DM (2004) Origins of perception: retinal ganglion cell diversity and the creation of parallel visual pathways. In: The cognitive neurosciences III (Gazzaniga MS, ed), pp 281-301.

Dacey DM, Peterson BB, Robinson FR, Gamlin PD (2003) Fireworks in the primate retina: in vitro photodynamics reveals diverse LGN-projecting ganglion cell types. Neuron 37:15-27. CrossRef Medline

Demb JB, Zaghloul K, Haarsma L, Sterling P (2001a) Bipolar cells contribute to nonlinear spatial summation in the brisk-transient $(\mathrm{Y})$ ganglion cell in mammalian retina. J Neurosci 21:7447-7454. CrossRef Medline

Demb JB, Zaghloul K, Sterling P (2001b) Cellular basis for the response to second-order motion cues in $Y$ retinal ganglion cells. Neuron 32:711-721. CrossRef Medline

de Monasterio FM (1978) Properties of ganglion cells with atypical receptive-field organization in retina of macaques. J Neurophysiol 41: 1435-1449. CrossRef Medline

Derrington AM, Lennie P (1984) Spatial and temporal contrast sensitivities of neurones in lateral geniculate nucleus of macaque. J Physiol 357:219240. CrossRef Medline

Diamond IT, Conley M, Itoh K, Fitzpatrick D (1985) Laminar organization of geniculocortical projections in Galago senegalensis and Aotus trivirgatus. J Comp Neurol 242:584-610. CrossRef Medline

Dick A, Kaske A, Creutzfeldt OD (1991) Topographical and topological organization of the thalamocortical projection to the striate and prestriate cortex in the marmoset (Callithrix jacchus). Exp Brain Res 84:233-253. Medline

Eiber CD, Pietersen ANJ, Zeater N, Solomon SG, Martin PR (2018) Chromatic summation and receptive field properties of blue-on and blue-off cells in marmoset lateral geniculate nucleus. Vision Res 151:41-52. CrossRef Medline

Enroth-Cugell C, Robson JG (1966) The contrast sensitivity of retinal ganglion cells of the cat. J Physiol 187:517-552. CrossRef Medline

Fitzpatrick D, Itoh K, Diamond IT (1983) The laminar organization of the lateral geniculate body and the striate cortex in the squirrel monkey (Saimiri sciureus). J Neurosci 3:673-702. CrossRef Medline

Fukuda Y, Sumitomo I, Sugitani M, Iwama K (1979) Receptive-field properties of cells in the dorsal part of the albino rat's lateral geniculate nucleus. Jpn J Physiol 29:283-307. CrossRef Medline

Girard P, Salin PA, Bullier J (1992) Response selectivity of neurons in area MT of the macaque monkey during reversible inactivation of area V1. J Neurophysiol 67:1437-1446. CrossRef Medline

Gollisch T, Meister M (2010) Eye smarter than scientists believed: neural computations in circuits of the retina. Neuron 65:150-164. CrossRef Medline

Hale PT, Sefton AJ, Dreher B (1979) A correlation of receptive field properties with conduction velocity of cells in the rat's retino-geniculo-cortical pathway. Exp Brain Res 35:425-442. Medline

Harting JK, Casagrande VA, Weber JT (1978) The projection of the primate superior colliculus upon the dorsal lateral geniculate nucleus: autoradiographic demonstration of interlaminar distribution of tectogeniculate axons. Brain Res 150:593-599. CrossRef Medline

Heine WF, Passaglia CL (2011) Spatial receptive field properties of rat retinal ganglion cells. Vis Neurosci 28:403-417. CrossRef Medline

Hendry SH, Reid RC (2000) The koniocellular pathway in primate vision. Annu Rev Neurosci 23:127-153. CrossRef Medline

Hendry SH, Yoshioka T (1994) A neurochemically distinct third channel in the macaque dorsal lateral geniculate nucleus. Science 264:575-577. CrossRef Medline

Hochstein S, Shapley RM (1976) Linear and nonlinear spatial subunits in Y cat retinal ganglion cells. J Physiol 262:265-284. CrossRef Medline

Irvin GE, Norton TT, Sesma MA, Casagrande VA (1986) W-like response properties of interlaminar zone cells in the lateral geniculate nucleus of a primate (Galago crassicaudatus). Brain Res 362:254-270. CrossRef Medline

Jacoby J, Schwartz GW (2017) Three small-receptive-field ganglion cells in the mouse retina are distinctly tuned to size, speed, and object motion. J Neurosci 37:610-625. CrossRef Medline

Jones EG (2001) The thalamic matrix and thalamocortical synchrony. Trends Neurosci 24:595-601. CrossRef Medline

Kaplan E, Shapley RM (1982) X and Y cells in the lateral geniculate nucleus of macaque monkeys. J Physiol 330:125-143. CrossRef Medline

Kaplan E, Shapley RM (1986) The primate retina contains two types of ganglion cells, with high and low contrast sensitivity. Proc Natl Acad Sci U S A 83:2755-2757. CrossRef Medline

Klein C, Evrard HC, Shapcott KA, Haverkamp S, Logothetis NK, Schmid MC (2016) Cell-targeted optogenetics and electrical microstimulation reveal the primate koniocellular projection to supra-granular visual cortex. Neuron 90:143-151. CrossRef Medline

Kozak W, Rodieck RW, Bishop PO (1965) Responses of single units in lateral geniculate nucleus of cat to moving visual patterns. J Neurophysiol 28:19-47. CrossRef Medline

Kremers J, Kaas JH, Martin PR, Solomon SG (2005) The lateral geniculate nucleus. In: The primate visual system: a comparative approach (Kremers J, ed), pp 161-190. Hoboken: Wiley.

Kuffler SW (1953) Discharge patterns and functional organization of mammalian retina. J Neurophysiol 16:37-68. CrossRef Medline

Lee BB, Martin PR, Grünert U (2010) Retinal connectivity and primate vision. Prog Retin Eye Res 29:622-639. CrossRef Medline

Lennie P, Movshon JA (2005) Coding of color and form in the geniculostriate visual pathway. J Opt Soc Am A Opt Image Sci Vis 22:2013-2033. CrossRef Medline

Lennie P, Perry VH (1981) Spatial contrast sensitivity of cells in the lateral geniculate nucleus of the rat. J Physiol 315:69-79. CrossRef Medline

Levick WR (1967) Receptive fields and trigger features of ganglion cells in the visual streak of the rabbits retina. J Physiol 188:285-307. CrossRef Medline 
Levick WR, Thibos LN (1982) Analysis of orientation bias in cat retina. J Physiol 329:243-261. CrossRef Medline

Levick WR, Oyster CW, Takahashi E (1969) Rabbit lateral geniculate nucleus: sharpener of directional information. Science 165:712-714. CrossRef Medline

Masri RA, Percival KA, Koizumi A, Martin PR, Grünert U (2016) Survey of retinal ganglion cell morphology in marmoset. J Comp Neurol. Advance online publication. Retrieved December 20, 2016. doi: $10.1002 /$ cne.24157.

Maunsell JH, van Essen DC (1983) The connections of the middle temporal visual area (MT) and their relationship to a cortical hierarchy in the macaque monkey. J Neurosci 3:2563-2586. Medline

Naka K-I, Rushton WH (1966) S-potentials from colour units in the retina of fish (Cyprinidae). J Physiol 185:536-555. CrossRef Medline

Norton TT, Casagrande VA (1982) Laminar organization of receptive-field properties in lateral geniculate nucleus of bush baby (Galago crassicaudatus). J Neurophysiol 47:715-741. CrossRef Medline

Percival KA, Koizumi A, Masri RA, Buzás P, Martin PR, Grünert U (2014) Identification of a pathway from the retina to koniocellular layer K1 in the lateral geniculate nucleus of marmoset. J Neurosci 34:3821-3825. CrossRef Medline

Petrusca D, Grivich MI, Sher A, Field GD, Gauthier JL, Greschner M, Shlens J, Chichilnisky EJ, Litke AM (2007) Identification and characterization of a Y-like primate retinal ganglion cell type. J Neurosci 27:11019-11027. CrossRef Medline

Pietersen AN, Cheong SK, Solomon SG, Tailby C, Martin PR (2014) Temporal response properties of koniocellular (blue-on and blue-off) cells in marmoset lateral geniculate nucleus. J Neurophysiol 112:1421-1438. CrossRef Medline

Puller C, Manookin MB, Neitz J, Rieke F, Neitz M (2015) Broad thorny ganglion cells: a candidate for visual pursuit error signaling in the primate retina. J Neurosci 35:5397-5408. CrossRef Medline

Rodieck RW, Stone J (1965) Analysis of receptive fields of cat retinal ganglion cells. J Neurophysiol 28:833-849. CrossRef Medline

Rodman HR, Gross CG, Albright TD (1989) Afferent basis of visual response properties in area MT of the macaque. I. effects of striate cortex removal. J Neurosci 9:2033-2050. CrossRef Medline

Rodman HR, Gross CG, Albright TD (1990) Afferent basis of visual response properties in area MT of the macaque: II. effects of superior colliculus removal. J Neurosci 10:1154-1164. CrossRef Medline

Rosa MG, Tweedale R, Elston GN (2000) Visual responses of neurons in the middle temporal area of new world monkeys after lesions of striate cortex. J Neurosci 20:5552-5563. CrossRef Medline

Roy S, Jayakumar J, Martin PR, Dreher B, Saalmann YB, Hu D, Vidyasagar TR (2009) Segregation of short-wavelength sensitive (S) cone signals in the macaque dorsal lateral geniculate nucleus. Eur J Neurosci 30:1517-1526. CrossRef Medline

Sceniak MP, Ringach DL, Hawken MJ, Shapley R (1999) Contrast's effect on spatial summation by macaque V1 neurons. Nat Neurosci 2:733-739. CrossRef Medline

Schiller PH, Malpeli JG (1977) Properties and tectal projections of monkey retinal ganglion cells. J Neurophysiol 40:428-445. CrossRef Medline

Schiller PH, Stryker M, Cynader M, Berman N (1974) Response characteristics of single cells in the monkey superior colliculus following ablation or cooling of visual cortex. J Neurophysiol 37:181-194. CrossRef Medline

Schiller PH, Logothetis NK, Charles ER (1990) Role of the color-opponent and broad-band channels in vision. Vis Neurosci 5:321-346. CrossRef Medline

Schmid MC, Mrowka SW, Turchi J, Saunders RC, Wilke M, Peters AJ, Ye FQ, Leopold DA (2010) Blindsight depends on the lateral geniculate nucleus. Nature 466:373-377. CrossRef Medline

Sclar G, Maunsell JHR, Lennie P (1990) Coding of image contrast in central visual pathways of the macaque monkey. Vision Res 30:1-10. CrossRef Medline

Sincich LC, Park KF, Wohlgemuth MJ, Horton JC (2004) Bypassing V1: a direct geniculate input to area MT. Nat Neurosci 7:1123-1128. CrossRef Medline

Sincich LC, Adams DL, Economides JR, Horton JC (2007) Transmission of spike trains at the retinogeniculate synapse. J Neurosci 27:2683-2692. CrossRef Medline

Sivyer B, Venkataramani S, Taylor WR, Vaney DI (2011) A novel type of complex ganglion cell in rabbit retina. J Comp Neurol 519:3128-3138. CrossRef Medline

Solomon SG, Martin PR, White AJ, Rüttiger L, Lee BB (2002) Modulation sensitivity of ganglion cells in peripheral retina of macaque. Vision Res 42:2893-2898. CrossRef Medline

Solomon SG, Tailby C, Cheong SK, Camp AJ (2010) Linear and nonlinear contributions to the visual sensitivity of neurons in primate lateral geniculate nucleus. J Neurophysiol 104:1884-1898. CrossRef Medline

Soodak RE, Shapley RM, Kaplan E (1987) Linear mechanism of orientation tuning in the retina and lateral geniculate nucleus of the cat. J Neurophysiol 58:267-275. CrossRef Medline

Stepniewska I, Qi HX, Kaas JH (2000) Projections of the superior colliculus to subdivisions of the inferior pulvinar in new world and old world monkeys. Vis Neurosci 17:529-549. CrossRef Medline

Stone J, Fabian M (1966) Specialized receptive fields of the cat's retina. Science 152:1277-1279. CrossRef Medline

Stone J, Fukuda Y (1974) Properties of cat retinal ganglion cells: a comparison of W-cells with X- and Y-cells. J Neurophysiol 37:722-748. CrossRef Medline

Szmajda BA, Buzás P, Fitzgibbon T, Martin PR (2006) Geniculocortical relay of blue-off signals in the primate visual system. Proc Natl Acad Sci U S A 103:19512-19517. CrossRef Medline

Szmajda BA, Grünert U, Martin PR (2008) Retinal ganglion cell inputs to the koniocellular pathway. J Comp Neurol 510:251-268. CrossRef Medline

Tailby C, Solomon SG, Dhruv NT, Majaj NJ, Sokol SH, Lennie P (2007) A new code for contrast in the primate visual pathway. J Neurosci 27:39043909. CrossRef Medline

Tailby C, Szmajda BA, Buzás P, Lee BB, Martin PR (2008) Transmission of blue $(\mathrm{S})$ cone signals through the primate lateral geniculate nucleus. J Physiol 586:5947-5967. CrossRef Medline

Tailby C, Cheong SK, Pietersen AN, Solomon SG, Martin PR (2012) Colour and pattern selectivity of receptive fields in superior colliculus of marmoset monkeys. J Physiol 590:4061-4077. CrossRef Medline

Troy JB, Einstein G, Schuurmans RP, Robson JG, Enroth-Cugell C (1989) Responses to sinusoidal gratings of two types of very nonlinear retinal ganglion cells of cat. Vis Neurosci 3:213-223. CrossRef Medline

van Wyk M, Taylor WR, Vaney DI (2006) Local edge detectors: a substrate for fine spatial vision at low temporal frequencies in rabbit retina. J Neurosci 26:13250-13263. CrossRef Medline

Vaney DI, Levick WR, Thibos LN (1981) Rabbit retinal ganglion cells: receptive field classification and axonal conduction properties. Exp Brain Res 44:27-33. Medline

Warner CE, Goldshmit Y, Bourne JA (2010) Retinal afferents synapse with relay cells targeting the middle temporal area in the pulvinar and lateral geniculate nuclei. Front Neuroanat 4:8/1-8/16. CrossRef Medline

White AJ, Solomon SG, Martin PR (2001) Spatial properties of koniocellular cells in the lateral geniculate nucleus of the marmoset Callithrix jacchus. J Physiol 533:519-535. CrossRef Medline

Wiesel TN, Hubel DH (1966) Spatial and chromatic interactions in the lateral geniculate body of the rhesus monkey. J Neurophysiol 29:1115-1156. CrossRef Medline

Wilson PD, Rowe MH, Stone J (1976) Properties of relay cells in cat's lateral geniculate nucleus: a comparison of W-cells with X-and Y-cells. J Neurophysiol 39:1193-1209. CrossRef Medline

Xu X, Ichida JM, Allison JD, Boyd JD, Bonds AB, Casagrande VA (2001) A comparison of koniocellular, magnocellular and parvocellular receptive field properties in the lateral geniculate nucleus of the owl monkey (Aotus trivirgatus). J Physiol 531:203-218. CrossRef Medline

Yamada ES, Bordt AS, Marshak DW (2005) Wide-field ganglion cells in macaque retinas. Vis Neurosci 22:383-393. CrossRef Medline

Yu HH, Chaplin TA, Egan GW, Reser DH, Worthy KH, Rosa MG (2013) Visually evoked responses in extrastriate area MT after lesions of striate cortex in early life. J Neurosci 33:12479-12489. CrossRef Medline

Yukie M, Iwai E (1981) Direct projection from the dorsal lateral geniculate nucleus to the prestriate cortex in macaque monkeys. J Comp Neurol 201:81-97. CrossRef Medline

Zeater N, Buzás P, Dreher B, Grünert U, Martin PR (2018) Projections of three subcortical visual centres to marmoset lateral geniculate nucleus. J Comp Neurol. Advance online publication. Retrieved January 9, 2018. doi: 10.1002/cne.24390. 